Faculdade de Economia da Universidade de Coimbra

Grupo de Estudos Monetários e Financeiros (GEMF)

Av. Dias da Silva, 165 - 3004-512 COIMBRA, PORTUGAL gemf@fe.uc.pt

http://www4.fe.uc.pt/gemf

CARLOS FONSECA MARINHEIRO

Output Smoothing in EMU and OECD:

Can We Forego Government Contribution?

A risk sharing approach

\title{
ESTUDOS DO GEMF
}

N. ${ }^{0} 2$

2003

PUBLICAÇ̃̃O CO-FINANCIADA PELA FUNDAÇÃO PARA A CIÊNCIA E TECNOLOGIA

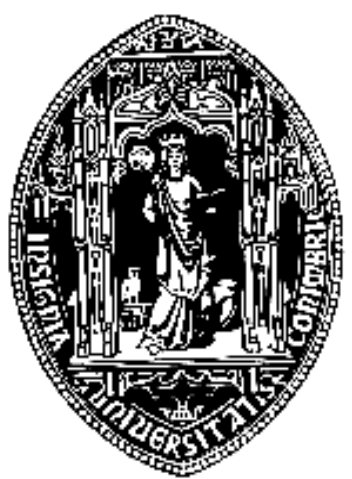




\title{
OUTPUT SMOOTHING IN EMU AND OECD: CAN WE FOREGO GOVERNMENT CONTRIBUTION? A RISK SHARING APPROACH
}

\author{
Carlos Fonseca Marinheiro* \\ (Faculdade de Economia da Universidade de Coimbra, and \\ Katholiek Universiteit Leuven)
}

\begin{abstract}
This paper analyses the smoothing of asymmetric shocks to output for a sample of OECD countries. The research finds no evidence of large differences in the patterns of risk sharing for the 19 OECD countries, the EU-15 or euro-area countries, for the period 1970-1999. However, there were shown to be considerable differences between the euro-area and the successful monetary union of the USA: the euro-area showed a much lower insurance of asymmetric shocks than the US states. In the US federation, $75 \%$ of the asymmetric shocks to output were smoothed in the period 1964-1990. However, in the euro-area only 44\% of such shocks were not passed onto consumption in the period 1970-1999. Until increasing economic integration in Europe does not lead to a substantial decrease in the incidence of idiosyncratic shocks, such shocks may impose non-negligible welfare costs.

Due to a large contribution from the public sector to risk sharing, especially to smooth out more persistent shocks, it does not seem likely that private capital markets can easily replace the government, in the near future, in providing a sufficient degree of risk sharing in the euro-area. Even if capital markets become as integrated in the euro-area as they were in the US federation in the period 1964-1990, the amount of shocks left unsmoothed will still be 1.8 times larger than in the US federation. As there are no substantial differences between the patterns of risk sharing for the different samples considered, an eventual enlargement of the euro-area to include the UK, Denmark and Sweden is not likely to pose additional risk sharing problems for the euro-zone.
\end{abstract}

Keywords: EMU; Output smoothing; Risk sharing; International capital markets; Economic integration.

JEL classification: E21; E62; F15; F36.

\footnotetext{
${ }^{1 *}$ Correspondence to: Faculdade de Economia, Universidade de Coimbra, Av. Dias da Silva 165, P-3004-512 Coimbra, Portugal. E-mail: marinheiro@fe.uc.pt. Web address: http://www4.fe.uc.pt/carlosm. This research is based on my PhD dissertation in Economics at the Catholic University of Leuven, and was prepared for the Workshop on "Monetary Union after EMU", CESifo Venice Summer Institute, $21^{\text {st }}-22^{\text {nd }}$ July 2003. I am extremely grateful to my supervisor, Prof. Paul De Grauwe, for his most helpful comments. I would also like to thank Prof. Bent Sørensen for making his data set available and for the GAUSS econometric program used for calculations regarding the US states. Any errors that may remain are solely my responsibility. This research received financial support from the FCT, under the Sub-programme Science and Technology of the $2^{\text {nd }}$ Community Support Framework to Portugal.
} 


\section{Contents}

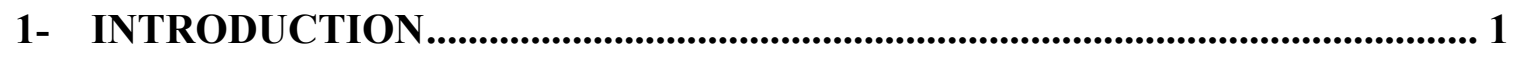

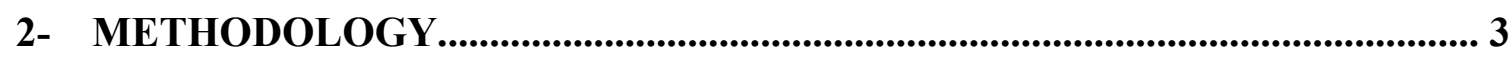

3- EMPIRICAL RESULTS FOR EURO-AREA AND OECD COUNTRIES ........ 7

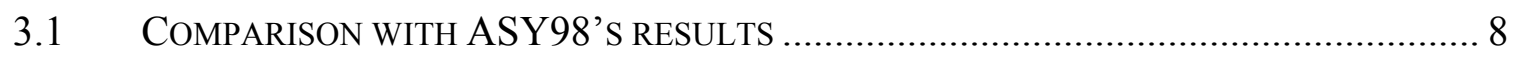

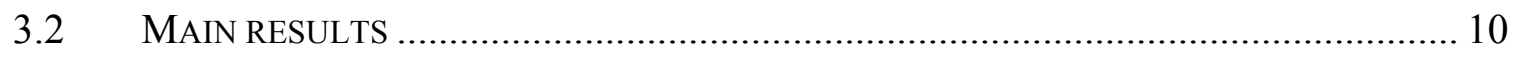

3.3 THE CONTRIBUTION MADE BY PRIVATE AND GOVERNMENT SECTORS TO

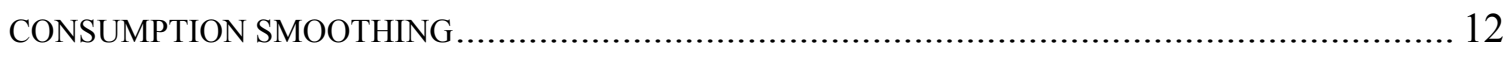

3.4 CONSUMPTION SMOOTHING: HIGH VS. LOW DEFICIT COUNTRIES........................... 13

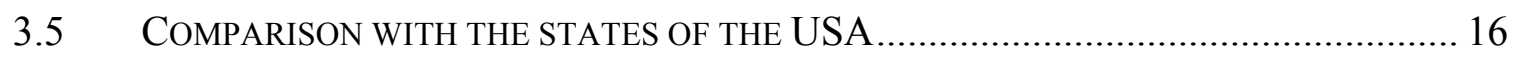

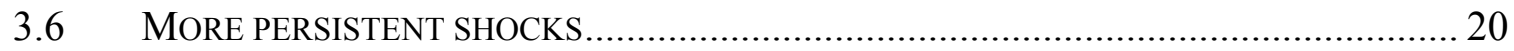

3.7 EVOLUTION OF SMOOTHING PATTERNS OVER TIME ......................................... 22

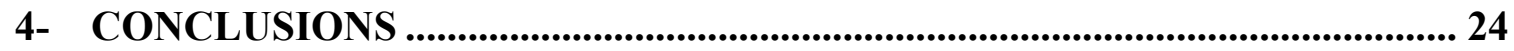

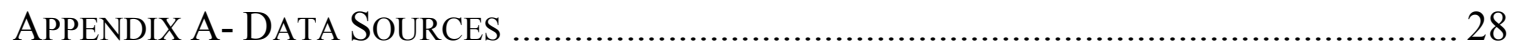

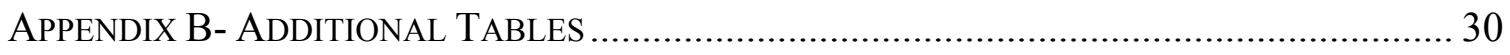

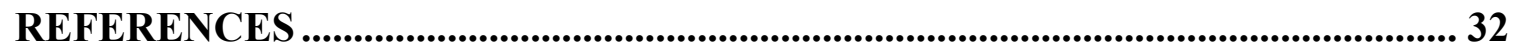

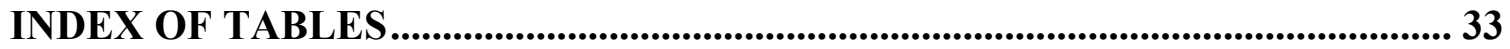




\section{1- Introduction}

This paper analyses the patterns of output smoothing for the euro-area and for OECD economies, and identifies the different channels of risk sharing among such countries. It also compares the results obtained with those of the US states. By taking the successful monetary union of the USA as a benchmark, interesting conclusions can be drawn concerning the degree of preparation of the EMU and OECD countries in dealing with asymmetric shocks. When countries give up their independent monetary policies, and the ability to use the exchange rate mechanism to engage in monetary union, they should be able to smooth out idiosyncratic shocks. If this is not the case, the constitution of the monetary union could be rather costly.

In the USA, the federal budget redistributes income among the different states. In Europe, the EMU has no similar tool for doing this, and the national fiscal policies are constrained by the Stability and Growth Pact (SGP). Is it possible to run successfully a monetary union without a central (federal) budget or with constrained national fiscal policies? In other words, what is the role of the government sector in smoothing out asymmetric shocks in OECD countries? Could the government sector be substituted by private capital markets to provide risk sharing? These are some of the questions that this study tries to answer.

In Europe, the EMU will certainly lead to increased financial integration among euro member countries, and financial markets will be able to contribute to smoothing out shocks in a monetary union. This contribution is made via two different channels. Firstly, individuals resident in a monetary union might share risk through the cross-ownership of assets. If asset portfolios are regionally diversified, their holders are better protected against asymmetric shocks. By holding internationally diversified portfolios, individuals can reduce the exposure of their income and wealth to national idiosyncratic shocks on output, which facilitates consumption smoothing. Secondly, in a monetary union, the economic agents are able to smooth the pattern of aggregated consumption by borrowing or lending internationally. Monetary union increases the depth of the credit market. Thus, if financial markets are sufficiently integrated, these mechanisms could play a crucial role in the smoothing of (asymmetric) business cycles and in the stability of the monetary union.

The degree of financial integration in Europe is still considerably less than in other monetary unions. However, the introduction of the euro in 1999, and the resulting disappearance of exchange rate risk among the $12 \mathrm{EU}$ countries, is leading to an increasing financial integration in the euro-area. According to the 'official consensus', the development of Euroland financial markets will help to accomplish a sufficient degree of risk sharing among EMU members, enabling them to smooth out asymmetric shocks. In this regard, the European Commission has put great emphasis on the study of Asdrubali, Sørensen and Yosha (1996), which concluded that, in the case of the U. S. States, financial markets play a much larger role than federal government transfers as channels of inter-state 
risk sharing. Such results enabled the Commission to conclude that "in Europe, more integrated capital and credit markets should greatly enhance the capacity of Member States to respond to shocks, as is presently the case for US states."2 Consequently, an analysis will be made here of how the increasing integration of the bond and equity markets in Euroland might enhance the potential of risk sharing among member states. In order to do so, the results obtained for Euroland will be compared with those of the US. This analysis is important because increasing risk sharing reduces the pressure exerted on the ECB, and on national fiscal authorities, to deal with shocks concentrated in one or more countries.

To sum up, besides the quantification of the importance of the different channels of risk sharing in both OECD and EU countries, this paper will:

a) Verify whether it is possible to identify a difference in the pattern of output smoothing between the euro-12 countries and the larger OECD group. More precisely, it will evaluate whether Euroland economies were better prepared in 1999 to enter monetary union than the other countries studied.

b) Assess the impact of the eventual enlargement of the euro area to include the UK, Sweden and Denmark.

c) Break down the smoothing provided by saving into government and private contributions. This division will shed light on the question regarding whether private capital markets can substitute governments in the role of smoothing output.

d) Determine whether the level of government deficit/debt has any impact on the pattern of risk sharing.

e) Compare the patterns of risk sharing in the OECD, in the EU-15, and in Euroland using the monetary union of the USA as a benchmark.

f) Study how the pattern of output smoothing has evolved over time. In this regard, it will be seen whether the degree of stabilisation provided by financial markets has increased over time, or not. This analysis will also be helpful in determining how output smoothing is likely to evolve in the near future.

g) Determine whether the size of countries has an effect on risk sharing patterns.

In order to accomplish these objectives, we will use the international extension of the aforementioned method of Asdrubali et al. (1996), as proposed by Sørensen and Yosha (1998). A panel data estimation will be used for the period 1970-1999 for the 19 OECD economies. The sample considered includes all $15 \mathrm{EU}$ economies (with the exception of Luxembourg) and the economies of Norway, the USA, Canada, Australia and Japan.

In comparison with previously published literature, this paper uses a significantly increased sample of data (both in terms of the number of years studied and the number of countries involved) and tests new and interesting hypotheses. More specifically, when compared with the study of Sørensen and Yosha (1998) the results given here have been widened to include the 1990s, and the sample of countries taken has been considerably enlarged from 8 EU countries to comprise all euro-area and EU-15 economies with the

\footnotetext{
${ }^{2}$ Buti and Sapir (1998: 29). 
exception of Luxembourg. Although this is the result of the imposition of some hypotheses in making data from different sources compatible, it enables us to make more reliable and interesting conclusions concerning the process of European integration. This paper also tests the above-mentioned hypotheses that, to the best of our knowledge, have not yet been tested in the literature.

\section{2- Methodology}

Different channels of risk sharing will be estimated for the period 1970-1999, for a group of 19 OECD economies, which includes all EU-15 economies (except Luxembourg) along with Norway, Canada, Australia, the USA, and Japan. The main source of data is the OECD national accounts statistics, complemented with other sources, as described in Appendix A. In order to identify the different channels of the smoothing of asymmetric shocks to GDP, we will use the method proposed by Sørensen and Yosha (1998). ${ }^{3}$ This method extends the method proposed by Asdrubali et al. (1996) for the US states, to an international level.

The method enables the identification of four different channels of income and consumption smoothing among different countries or regions:

- The first is factor income. When there is cross-ownership of productive assets, individuals of one country have claims on the output of other countries, as the national citizens that invested in other countries have the right to the return on that capital. The income derived from these cross-border financial investments will then co-move with the income of other countries. This enables income smoothing through the cross-border ownership of productive assets, and provides insurance against asymmetric shocks that might hit their own national economies.

- Secondly, international transfers smooth income if the net transfers from abroad are larger during idiosyncratic recessions.

- Thirdly, saving and dis-saving, i.e. inter-temporal consumption smoothing, may also contribute to inter-country consumption smoothing. Consumers may adjust their savings in response to income shocks; corporations may increase or decrease retained earnings in response to profitability shocks; and, government net savings may behave in a counter-cyclical or pro-cyclical way.

- And, finally, capital depreciation may also contribute to cross-country income smoothing.

The factor income effect is reflected in the National Accounts as the difference between gross domestic product (GDP) and gross national product (GNP). Net international

\footnotetext{
${ }^{3}$ Mélitz and Zumer (1999) propose a slightly different methodology, which considers additional variables. However, in our opinion the Sørensen and Yosha (1998) approach is preferred as it represents a more direct translation of the identity proposed for the U.S. states by Asdrubali et al. (1996). Furthermore, the additional vector of variables proposed by Mélitz and Zumer (1999) did not prove to be essential in the authors own international dimension estimation.
} 
transfers are measured as the difference between disposable national income (DNI) and national income (NI). ${ }^{4}$ The difference between total consumption and disposable income is total net saving, reflecting consumption smoothing. Capital depreciation is responsible for the difference between GNP and DNI. ${ }^{5}$

The benchmark of the method is full risk sharing. When risk is fully shared within a group of countries, the consumption of a country co-moves with world consumption but does not co-move with country specific shocks [see Arreaza, Sørensen and Yosha (1998: 8)], i.e.

$$
\mathrm{C}_{\mathrm{t}}^{\mathrm{i}}+\mathrm{G}_{\mathrm{t}}^{\mathrm{i}}=\mathrm{k}^{\mathrm{i} G D P_{\mathrm{t}}}
$$

where $\mathrm{k}^{\mathrm{i}}$ is a country specific constant representing the fixed proportion claims on world output of country i, $\mathrm{C}$ is private consumption and $\mathrm{G}$ is government consumption. ${ }^{6}$ As a result, each country's consumption growth is perfectly correlated with world consumption growth. According to Olivei (2000) there are three key assumptions behind full risk sharing with complete markets. First, it is necessary to have perfect capital mobility across countries. Secondly, asset markets must be complete, to ensure that all idiosyncratic consumption risks are insurable. This requires that individuals have available for trade in world capital markets a set of assets sufficiently large to cover all possible future contingencies. ${ }^{7}$ Thirdly, each country's output must be tradable in order to allow the trade on assets that involve claims on its domestic output to take place. If a portion of domestic output is non-tradable, it is not possible to put international trade claims on it. Consequently, it is not possible to diversify the risks arising from fluctuations in nontradable output in international asset markets; such risks must be borne entirely by domestic consumers. For (1) to hold, it is also necessary to assume perfect substitution between private and public consumption, as a well as the exogeneity of GDP shocks. A derivation of this equation can be found in Sørensen and Yosha (1998: 215-217). ${ }^{8}$ It should be remembered, however, that the purpose of this method is not to test the hypothesis of full risk sharing, but to break down the degree of observed (full or partial) risk sharing into several components.

In order to decompose the cross-sectional variance of shocks to GDP Sørensen and Yosha (1998), hereafter referred to as SY98, depart from the following identity:

\footnotetext{
${ }^{4}$ However, in our view, the difference between DNI and NI could involve some degree of smoothing through the government budget, which might give rise to an interaction with net government saving smoothing. Consider for example a tax cut that leads to an increased household's disposable income. If Ricardian equivalence does not hold, increased consumption results. The counterpart of the increased household's disposable income is an increase in government net lending. However, it is not possible to control this second order potential for interaction.

${ }^{5}$ Following OECD National Accounts concepts, GNP = GDP + net factor inflow to the country; NI = GNP depreciation; $\mathrm{DNI}=\mathrm{NI}+$ net international transfers; and, $\mathrm{C}+\mathrm{G}=\mathrm{NI}-$ net saving.

${ }^{6}$ Sørensen and Yosha (1998: 217) show that under the assumption of logarithm utility, the share of country i's world consumption is the discounted expected share of its future output in world consumption.

${ }^{7}$ This implies that a worker should be able to insure his labour income against unemployment and against all other contingencies that might occur Olivei (2000: 4).

${ }^{8}$ The derivation is based on the assumption of identical risk averse expected utility maximizer consumers.
} 


$$
\mathrm{GDP}^{\mathrm{i}}=\frac{\mathrm{GDP}^{\mathrm{i}}}{\mathrm{GNP}^{\mathrm{i}}} \frac{\mathrm{GNP}^{\mathrm{i}}}{\mathrm{NI}^{\mathrm{i}}} \frac{\mathrm{NI}^{\mathrm{i}}}{\mathrm{DNI}^{\mathrm{i}}} \frac{\mathrm{DNI}^{\mathrm{i}}}{\mathrm{C}^{\mathrm{i}}+\mathrm{G}^{\mathrm{i}}}\left(\mathrm{C}^{\mathrm{i}}+\mathrm{G}^{\mathrm{i}}\right)
$$

where all variables are measured in per capita real terms, ${ }^{9}$ and $i$ is an index of countries; the time index was suppressed. $\mathrm{C}+\mathrm{G}$ is the total consumption (the sum of private and public consumption). ${ }^{10}$ Taking logs and differences, multiplying both sides by $\Delta \log$ GDP $^{\mathrm{i}}$ (minus its mean), and taking the cross-sectional average, leads to the following decomposition of the cross-sectional variance of GDP:

$$
\begin{aligned}
\operatorname{var}\left\{\Delta \log \mathrm{GDP}^{\mathrm{i}}\right\}= & \operatorname{cov}\left\{\Delta \log \mathrm{GDP}^{\mathrm{i}}, \Delta \log \mathrm{GDP}^{\mathrm{i}}-\Delta \log \mathrm{GNP}^{\mathrm{i}}\right\} \\
& +\operatorname{cov}\left\{\Delta \log \mathrm{GDP}^{\mathrm{i}}, \Delta \log \mathrm{GNP}^{\mathrm{i}}-\Delta \log \mathrm{NI}^{\mathrm{i}}\right\} \\
& +\operatorname{cov}\left\{\Delta \log \mathrm{GDP}^{\mathrm{i}}, \Delta \log \mathrm{NI}^{\mathrm{i}}-\Delta \log \mathrm{DNI}^{\mathrm{i}}\right\} \\
& +\operatorname{cov}\left\{\Delta \log \mathrm{GDP}^{\mathrm{i}}, \Delta \log \mathrm{DNI}^{\mathrm{i}}-\Delta \log \left(\mathrm{C}^{\mathrm{i}}+\mathrm{G}^{\mathrm{i}}\right)\right\} \\
& +\operatorname{cov}\left\{\Delta \log \mathrm{GDP}^{\mathrm{i}}, \Delta \log \left(\mathrm{C}^{\mathrm{i}}+\mathrm{G}^{\mathrm{i}}\right)\right\}
\end{aligned}
$$

A further division by the variance of $\Delta \log \mathrm{GDP}^{\mathrm{i}}$ yields:

$$
1=\beta_{\mathrm{f}}+\beta_{\mathrm{d}}+\beta_{\tau}+\beta_{\mathrm{s}}+\beta_{\mathrm{u}}
$$

The $\beta$ coefficients are the coefficient estimates of the following panel regressions:

$$
\begin{aligned}
\Delta \log \mathrm{GDP}_{\mathrm{t}}^{\mathrm{i}}-\Delta \log \mathrm{GNP}_{\mathrm{t}}^{\mathrm{i}} & =\mathrm{v}_{\mathrm{f}, \mathrm{t}}+\beta_{\mathrm{f}} \Delta \log \mathrm{GDP}_{\mathrm{t}}^{\mathrm{i}}+\mathrm{u}_{\mathrm{f}, \mathrm{t}}^{\mathrm{i}} \\
\Delta \log \mathrm{GNP}_{\mathrm{t}}^{\mathrm{i}}-\Delta \log \mathrm{NI}_{\mathrm{t}}^{\mathrm{i}} & =v_{\mathrm{d}, \mathrm{t}}+\beta_{\mathrm{d}} \Delta \log \mathrm{GDP}_{\mathrm{t}}^{\mathrm{i}}+\mathrm{u}_{\mathrm{d}, \mathrm{t}}^{\mathrm{i}} \\
\Delta \log \mathrm{NI}_{\mathrm{t}}^{\mathrm{i}}-\Delta \log \mathrm{DNI}_{\mathrm{t}}^{\mathrm{i}} & =\mathrm{v}_{\tau, \mathrm{t}}+\beta_{\tau} \Delta \log \mathrm{GDP}_{\mathrm{t}}^{\mathrm{i}}+\mathrm{u}_{\tau, \mathrm{t}}^{\mathrm{i}} \\
\Delta \log \mathrm{DNI}_{\mathrm{t}}^{\mathrm{i}}-\Delta \log \left(\mathrm{C}_{\mathrm{t}}^{\mathrm{i}}+\mathrm{G}_{\mathrm{t}}^{\mathrm{i}}\right) & =v_{\mathrm{s}, \mathrm{t}}+\beta_{\mathrm{s}} \Delta \log \mathrm{GDP}_{\mathrm{t}}^{\mathrm{i}}+\mathrm{u}_{\mathrm{s}, \mathrm{t}}^{\mathrm{i}} \\
\Delta \log \left(\mathrm{C}_{\mathrm{t}}^{\mathrm{i}}+\mathrm{G}_{\mathrm{t}}^{\mathrm{i}}\right) & =v_{\mathrm{u}, \mathrm{t}}+\beta_{\mathrm{u}} \Delta \log \mathrm{GDP}_{\mathrm{t}}^{\mathrm{i}}+\mathrm{u}_{\mathrm{u}, \mathrm{t}}^{\mathrm{i}}
\end{aligned}
$$

where the $v_{\text {.,t }}$ are time fixed effects. According to SY98, the inclusion of these time effects is crucial in capturing year-specific impacts on growth rates, i.e. the impact of aggregated OECD production. The $\beta$ coefficients are interpreted as giving the incremental percentage amount of smoothing achieved at each level. $\beta_{\mathrm{f}}$ captures the amount of smoothing provided by factor income; $\beta_{\mathrm{d}}$ gives the amount of smoothing endorsed to capital depreciation flows; $\beta_{\mathrm{t}}$ captures the international transfers smoothing; $\beta_{\mathrm{s}}$ captures the smoothing provided by saving; and finally, $\beta_{\mathrm{u}}$ gives the percentage of shocks that are left unsmoothed. We will empirically estimate system (4). ${ }^{11}$

\footnotetext{
${ }^{9}$ The consumption deflator was used to deflate all variables, measuring the output and consumption of each country in terms of real consumption within that country.

${ }^{10}$ As mentioned in footnote 5, the variables are defined according to OECD National Account conventions.

${ }^{11}$ The purpose of this method is to discover the extent to which asymmetric shocks are smoothed. However, as only temporary shocks should be smoothed, this method should not capture permanent shocks. The first difference formulation and the time fixed effects should be sufficient to ensure that outcome. Moreover, Sørensen and Yosha (1998: note 23, p. 225) check the robustness of their main regressions using HodrickPrescott filtered data, reaching very similar results.
} 
The pioneering work of Asdrubali et al. (1996) for the US states identified only three levels of smoothing: capital market, federal government, and the credit market. Hence, the degree of detail is greater when different countries are considered. In fact, country level data is richer and less prone to measurement errors than US state level data. For instance, there are no official estimates for the GDP or GNP in the US states. Nevertheless, it is possible to aggregate the more detailed levels of smoothing of the international extension into the three channels obtained for the US states. It is only necessary to further divide the amount of smoothing that occurs via saving (in the international extension) into government saving, corporate saving, and personal saving. ${ }^{12}$ The capital market smoothing is then the result of the sum of the effects of factor income, capital depreciation, and corporate saving. US federal government smoothing (through the federal tax-transfer and grant system) is comparable with income smoothing via international transfers. Finally, US consumption smoothing via credit markets corresponds to smoothing through both personal and government saving.

\section{Panel data estimation comments}

As mentioned above, estimates will be based on panel data regressions. Compared with pure cross-section or time-series studies, the use of panel data has the advantage of allowing control of individual heterogeneity. Following Baltagi (2001), the general specification of a panel data regression is:

$$
\mathrm{Y}_{\mathrm{it}}=\alpha+\mathrm{X}_{\mathrm{it}}^{\prime} \beta+\mathrm{u}_{\mathrm{it}}, \quad \mathrm{i}=1, \ldots, \mathrm{N} ; \mathrm{t}=1, \ldots, \mathrm{T}
$$

The variables have a double subscript, $i$ for the individuals (countries, firms, households, etc.), and $t$ for time. These subscripts reflect the cross-section and the timeseries dimensions, respectively. The error component disturbances take the following structure:

$$
\mathrm{u}_{\mathrm{it}}=\mu_{\mathrm{i}}+\lambda_{\mathrm{t}}+\mathrm{v}_{\mathrm{it}}
$$

where $\mu_{\mathrm{i}}$ stands for the unobservable individual-specific effect, $\lambda_{t}$ is the unobservable time effect and $v_{i t}$ is the remainder stochastic disturbance term independent and identically distributed, IID $\left(0, \sigma^{2}{ }_{v}\right)$.

Either the fixed effects model or the random effects model can be used depending on the assumptions made on the unobservable components of the error term. In our practical estimation the time fixed effects model will be used, i.e. it will be assumed that $\lambda_{t}$ is fixed, $\mu_{\mathrm{i}}$ is nil and $v_{\mathrm{it}}$ is stochastic. Furthermore, the $\mathrm{X}_{\mathrm{it}}$ will be assumed to be independent of $v_{\mathrm{it}}$ for all $i$ and $t$.

When using fixed effects, the inference is conditional on the particular set of countries and over the specific time periods observed. Some of the known limitations of the use of

\footnotetext{
${ }^{12}$ Corporate saving smoothing essentially captures the effect of retained earnings behaviour. If, when profits decrease, the amount of dividends remains more or less the same (due to a reduction in retained earnings), corporations contribute to income smoothing (assuming that individuals do not see through the corporate veil).
} 
time fixed effects are the large loss of degrees of freedom, ${ }^{13}$ and the impossibility of estimating the effect of any time-invariant variables, due to the way that the estimators are obtained. $^{14}$

Another possibility would be to estimate the model using random effects. In this case, it would be assumed that both $\mu_{\mathrm{i}}$ and $\lambda_{\mathrm{t}}$ were random. This would avoid the loss of degrees of freedom implied by the use of fixed effects, and the inference would pertain to the large population from which the sample was drawn. However, this technique would only be appropriate if we were drawing the $\mathrm{N}$ individuals randomly from a large population. Thus, it would be necessary to have a representative panel of the whole population we were trying to make inferences about. This is clearly not the case here: we are considering 19 OECD countries, i.e. almost the whole population of the developed OECD members. Moreover, as the sample will be split into sub-samples, we need our conclusions to be conditional on the particular sub-sample that is being used. In short, and in this particular case, the econometric theory clearly points to the use of the fixed effects model.

When using the time fixed effects model, we can choose from using individual fixed effects, time fixed effects, or both. As Sørensen and Yosha (1998: 224-225) point out, the use of time fixed effects is "crucial" in this application, given that they capture yearspecific impacts on GDP growth rates, i.e. the impact of aggregate OECD GDP. As a result, time fixed effects will also be used in our empirical estimates to make them comparable to those of Arreaza et al. (1998) and Sørensen and Yosha (1998), hereafter referred to as ASY98, and SY98 respectively.

The system (4) was estimated by SY98 and ASY98 using a two-step Generalised Least Squares (GLS) method (assuming a common AR1 process and allowing for state specific variances of the error terms since GDP is in general more volatile for small countries). In our empirical estimation will also correct for autocorrelation, but in a different way from that of ASY98: a common AR1 process will not be imposed for all equations.

\section{3- Empirical results for euro-area and OECD countries}

Our main results use a sample of 19 OECD economies ${ }^{15}$ for the period 1970-1999. ${ }^{16}$ The presentation of these results begins with a replication of those of ASY98, and is followed by our main results. Then the contribution of saving to smoothing will be divided into private and government components. Whether the level of deficit/debt has any

\footnotetext{
${ }^{13}$ The estimators are obtained using time or individual dummies.

${ }^{14}$ The time-invariant variables 'disappear' when the within regression is estimated, which uses deviations from the time average.

${ }^{15}$ The sample includes all EU economies (except Luxembourg), along with Norway, Canada, Australia, USA, and Japan.

${ }^{16}$ As the estimation requires a calculation of the growth rates, we loose the first observation, thus reducing the sample length to the 1971-1999 period.
}

G.E.M.F. - F.E.U.C. 
influence on the smoothing provided by the public and private sectors will also be investigated. Next, our results will be compared with those obtained for the US states. Subsequently, the way in which the pattern of risk sharing changes when the economy faces more persistent shocks will be analysed. Finally, an analysis will be made of the evolution of the pattern of risk sharing over time.

\subsection{Comparison with ASY98's results}

The presentation of our results begins with a replication (and extension) of those obtained by Arreaza et al. (1998) ${ }^{17}$ in Table 1. Columns (1) and (4) show ASY98 results for 8 and 11 European Union economies, respectively. ${ }^{18}$ Columns (2) and (5) show our own replication.

Table 1- Channels of income and consumption spending (\%)- Replication and extension of the results of ASY (1998, table 3.1)

\begin{tabular}{|c|c|c|c|c|c|c|c|}
\hline & \multicolumn{3}{|c|}{ EU-8 } & \multicolumn{4}{|c|}{ EU-11* } \\
\hline & \multirow{2}{*}{$\begin{array}{c}\operatorname{ASY}(98) \\
(1)\end{array}$} & \multicolumn{2}{|c|}{ Own estimate } & \multirow{2}{*}{$\frac{\operatorname{ASY}(98)}{(4)}$} & \multicolumn{3}{|c|}{ Own estimate } \\
\hline & & (2) & (3) & & (5) & (6) & (7) \\
\hline & $1971-93$ & $1971-93$ & $1971-99$ & $1980-93$ & $1980-93$ & $1980-99$ & $1971-99$ \\
\hline \multirow[t]{2}{*}{ Factor income $\left(\beta_{\mathrm{f}}\right)$} & -1 & 0 & -2 & -3 & -4 & -7 & -4 \\
\hline & (1) & (0) & (1) & (2) & (1) & (3) & (2) \\
\hline \multirow[t]{2}{*}{ Capital Depreciation $\left(\beta_{d}\right)$} & -8 & -11 & -11 & -8 & -13 & -14 & -12 \\
\hline & (8) & (7) & (8) & (8) & (6) & (7) & (9) \\
\hline International & 3 & 2 & 2 & 5 & 4 & 4 & 2 \\
\hline Transfers $\left(\beta_{t}\right)$ & (2) & (1) & (2) & (3) & (3) & (3) & (2) \\
\hline \multirow[t]{2}{*}{ Saving $\left(\beta_{\mathrm{s}}\right)$} & 50 & 53 & 54 & 37 & 42 & 48 & 54 \\
\hline & (10) & $(10)$ & (11) & (7) & (6) & (7) & (13) \\
\hline \multirow[t]{2}{*}{ Not Smoothed $\left(\beta_{\mathrm{u}}\right)$} & 56 & 56 & 58 & 69 & 70 & 70 & 60 \\
\hline & (14) & (11) & (13) & (14) & (11) & (13) & (15) \\
\hline
\end{tabular}

Notes: Absolute T-stats in brackets. Arreaza et al. (1998) report standard errors in their tables, thus the corresponding T-stats for ASY98 were obtained by dividing the coefficient estimate by its standard deviation, ignoring any (nonreported) rescaling. In our estimates we corrected for first order serial correlation (AR1) using a two-step search procedure in Winrats 5.01. Where necessary, results were rescaled to sum 100\%. The ASY98's EU8 sample comprises: Austria, Belgium, Denmark, France, Greece, Germany, and the UK. The ASY98 EU-11* sample consists of: EU8 + Italy, Netherlands, and Sweden. It does not correspond to the first euro-11 countries.

Despite some probable revisions of data, and a slightly different estimation method, ${ }^{19}$ very similar results to those of ASY $98^{20}$ were obtained. For the 1971-93 period and for the

\footnotetext{
${ }^{17}$ The results of ASY98 have the advantage of being more up-to-date than those of SY98.

${ }^{18}$ The sample of eleven EU economies does not correspond to the first euro-11 countries.

19 As already mentioned above, in contrast to ASY98, we do not impose an identical autocorrelation parameter across equations.

${ }^{20}$ In general, our results in column 5, for EU-11*, are more similar to the results of ASY98 represented in column 1 for the OECD than to ASY98's results for EU-11* (column 4). More specifically, the low level of smoothing provided by saving for EU-11* countries is not present in our estimations. In fact, for the period
} 
EU8 sample, the amount of unsmoothed shocks is exactly the same, but there are some small differences in the composition of smoothing. For the EU-11* sample and for the period 1980-93, comparing our results (column 5) with original ASY98 results (column 4), we can conclude that the percentage of unsmoothed shocks is roughly the same $(70 \%)$. Irrespective of the estimate, the large difference in the amount of shocks left unsmoothed in the OECD countries when compared to US states ${ }^{21}$ is striking. However, there are some differences in the composition of channels responsible for the smoothing of shocks: capital depreciation and factor income show a more negative dis-smoothing effect in our estimate, which in turn is compensated for by increased smoothing by saving.

Extending the duration of the EU8 sample to the end of the 1990s (column 3), has no major effect on the results: factor income is found to destabilise output, while the smoothing provided by saving shows a marginal increase. The overall result is only a small increase in the percentage of unsmoothed shocks (from $56 \%$ to $58 \%$ ).

With regard to the sample of 11 European economies, extending the results to 1999 leaves the amount of unsmoothed shocks unaltered. However, there is an increase in the amount of dis-smoothing by factor income (and capital depreciation) that is being compensated for by an increase in smoothing by saving. However, it should also be mentioned that the coefficient on factor income $\left(\beta_{\mathrm{f}}\right)$ is generally estimated with low precision, as reflected in the relatively low T-statistics. Extending the estimation period back to 1971 , i.e. adding the 1970 s to the sample, leads to a decrease in the percentage of unsmoothed shocks, which is a result both of a decrease in the dis-smoothing by factor income and capital depreciation and an increase in the smoothing provided by saving. This reflects the fact that the last two decades of the $\mathrm{XX}^{\text {th }}$ century where characterized by a lower degree of income smoothing than the more extended 1971-99 period: the amount of shocks to income left unsmoothed for the period of 1971-99 (and for EU-11) is 10 percentage points lower than for the 1980-99 period. As we shall see later, this is mainly the result of including the first half of the 1990s. Some possible explanations are related to the events that occurred in that period.

The early 1990s were characterized by extraordinary events that particularly affected Europe: first, there was the collapse of the USSR, then German reunification and the September 1992 crisis regarding the European Monetary System (EMS). ${ }^{22}$ The break up of the USSR had clear negative impact on Nordic countries' (especially Finland's) exports to the former USSR area. Moreover, some of the mechanisms advanced by Krugman (1993) might also have played a role. That is, the negative shock to Finland's GDP might have induced an exodus of capital that may have caused an even larger negative variation on

1971-99, the amount of shocks smoothed by saving, and the amount of shocks left unsmoothed, are very similar between both samples of countries.

${ }^{21}$ According to ASY96, only $19 \%$ of shocks to each state GSP were left unsmoothed in the US federation, in the period 1981-1990. Hence, the amount of risk sharing among OECD and EU countries is substantially inferior to its counterpart in the US states. In point 3.5, below, we will make a detailed comparison of the results obtained for the OECD and EU countries with the results regarding the US states.

${ }^{22}$ See, Gros and Thygesen (1998) for a detailed analysis of the EMS crisis. 
such countries' GNP, which might help to explain the negative coefficient of factor income smoothing. German reunification, the subsequent tightening of monetary policy all over Europe, and the EMS crisis may also have decreased the potential for risk sharing.

\subsection{Main results}

Table 2 shows our main results, divided into different sub-samples of countries for the period of 1970-1999.

Table 2- Channels of income and consumption spending (\%)- different country samples 1970-1999

\begin{tabular}{|c|c|c|c|c|c|c|c|c|c|}
\hline & All & Small & EU15 & EU11 & EU12 & $\begin{array}{l}\text { Small } \\
\text { EU15 }\end{array}$ & G7 & $\begin{array}{c}\text { South } \\
\text { periphery } \\
\text { EU }\end{array}$ & $\begin{array}{c}\text { Core } \\
\text { EU }\end{array}$ \\
\hline \multirow[t]{2}{*}{ Factor income $\left(\beta_{\mathrm{f}}\right)$} & -2 & -1 & -1 & -1 & 0 & -1 & -2 & -3 & 2 \\
\hline & (1) & (1) & (1) & (1) & (0) & (0) & (1) & (1) & (1) \\
\hline Capital & -7 & -7 & -7 & -7 & -7 & -8 & -8 & -3 & -11 \\
\hline Depreciation $\left(\beta_{\mathrm{d}}\right)$ & (7) & (6) & (6) & (5) & (6) & (6) & (4) & (1) & (4) \\
\hline International & -1 & -2 & -1 & -3 & -2 & -3 & 2 & 1 & 3 \\
\hline Transfers $\left(\beta_{t}\right)$ & (1) & (2) & (1) & (2) & (2) & (2) & (3) & (0) & (2) \\
\hline \multirow[t]{2}{*}{ Saving $\left(\beta_{\mathrm{s}}\right)$} & 50 & 52 & 51 & 51 & 53 & 52 & 47 & 41 & 44 \\
\hline & (15) & (12) & (12) & (9) & (11) & (10) & (9) & (4) & (5) \\
\hline \multirow[t]{2}{*}{ Not Smoothed $\left(\beta_{\mathrm{u}}\right)$} & 59 & 59 & 59 & 60 & 56 & 59 & 60 & 64 & 62 \\
\hline & $(20)$ & (16) & (16) & (13) & (13) & (14) & (13) & (6) & (7) \\
\hline \multicolumn{10}{|c|}{ 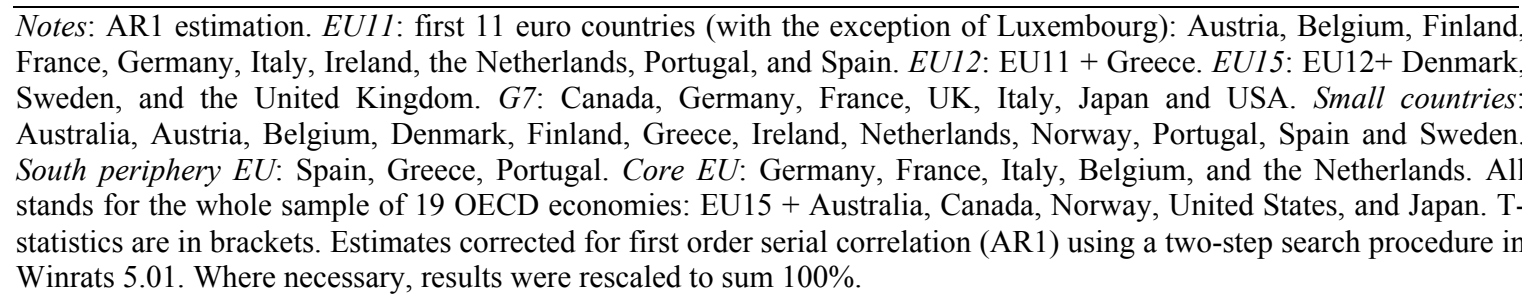 } \\
\hline
\end{tabular}

Focusing on the results for the whole sample of 19 OECD economies, it can be seen that only $41 \%$ of shocks to GDP among countries were smoothed. The only channel that effectively smoothes income is saving (50\%), while all other channels that might potentially smooth income are actually leading to income dis-smoothing: factor income flows dis-smoothed output by $-2 \%,{ }^{23}$ capital depreciation also has a negative contribution of $-7 \%$; and international transfers have a non-statistically significant impact of $-1 \%$. With the exception of the negative contribution from international transfers, the results are similar to those of ASY98 for the period 1971-1993.

The lack of smoothing through factor income flows might be interpreted as the result of the absence of significant cross-ownership of productive assets among OECD

\footnotetext{
${ }^{23}$ However, as the low t-statistic indicates, the coefficient on factor income smoothing is not statistically different from zero.
} 
economies. This result is inline with the usual 'home bias' in the composition of portfolios. Moreover, the contagious effect in financial markets might also limit risk-sharing benefits from holding an internationally diversified portfolio. ${ }^{24}$ International transfers do not seem to be motivated by income smoothing motivations. In the EU such transfers are mainly due to the Common Agricultural Policy (CAP), structural funds and their counterpart - the member states contributions to the EU budget. However, the resources of the EU budget have a ceiling of $1.27 \%$ of the Union's GNP (the actual figure in 2001 was $1.11 \%$ of GNP). Consequently, the EU budget has a very small influence on the European Union's income, limiting its contribution to the smoothing of output shocks. Capital depreciation is responsible for the difference between National Income and GNP. Its negative contribution to smoothing may be in part the result of how national accounts data is calculated. ${ }^{25}$

As mentioned above, saving is the only operative smoothing channel. ${ }^{26}$ It is the result of the net saving decisions of households, corporations and governments. This aggregated figure will be subdivided below into government and private contributions. While smoothing via saving does not necessarily require actual cross-country flows of funds, it may involve such flows given that aggregate consumption smoothing via saving is more difficult in a closed economy (SY98: 227).

In the same table, our sample of countries has been divided into different subsamples. As mentioned in the introduction, we wish to test a set of interesting hypotheses, namely to determine whether the size of a country has any relevance to patterns of output smoothing among countries. Consequently, we considered the G7 group of large countries separately from the group of small countries, within which the EU members were also isolated. We also wish to determine whether European Union (EU) countries and euro-area economies are in any way different from the larger OECD group. Hence, we isolated EU15 countries, the euro-area economies (both the present 12 members and the first 11 members). Furthermore, and in the spirit of Bayoumi and Eichengreen (1993) the "EU core" and the EU southern "periphery" were also considered.

As for the results regarding the different sub-samples, we can state that in general no considerable differences are to be found among such groups of countries. In fact, the picture for those sub-samples is not considerably different from the pattern of risk sharing for the entire sample. There are, however, a few interesting exceptions. The first exception is the positive contribution made by factor income flows to the 'core' EU countries, reflecting the impact of the cross-ownership of assets. It could be that individuals in the 'core' economies of the EU hold a more regionally diversified portfolio of assets than the

\footnotetext{
${ }^{24}$ In our opinion, the best way to diversify risk in increasingly integrated international financial markets, characterized by ever more correlated returns, is the holding of sector-diversified portfolios.

${ }^{25}$ Capital depreciation follows rigid accounting rules, being more or less independent of the business cycle. If, in reality, capital depreciation were affected by the business cycle, we would expect capital depreciation to decrease in recessions (reflecting a lower utilisation of productive capacity), leading to a lower volatility of NI with respect to GNP, and in that way to a positive $\beta_{\mathrm{d}}$ coefficient. However, such events are not likely to be captured in National Accounts data.

${ }^{26}$ Moreover, its coefficients are all statistically significant.
}

G.E.M.F. - F.E.U.C. 
rest of our sample of countries, due to a larger degree of integration of their economies. Another exception is the positive role played by international transfers for the subset of G7 economies, 'core' EU countries and the three southern 'peripheral' countries of the EU. However, all these subgroups of countries have a larger amount of shocks left unsmoothed (62\% for the EU 'core' against 59\% for all EU15). This result is due to a small degree of smoothing through saving, particularly for southern 'peripheral' EU countries and for the EU 'core', where saving only smoothes $41 \%$ and $44 \%$ respectively of shocks. The EU15 figure stands at $51 \%$.

\subsection{The contribution made by private and government sectors to consumption smoothing}

As mentioned above, the impact of net saving on the smoothing of consumption is the result of the net saving behaviour of three sectors: households, corporations and the government. It is very interesting to find out which of these three sectors contributes the most to smoothing. Due to data availability limitations, we are only going to differentiate between two sectors: the government and the private. In the private sector, there are contributions made by both personal saving behaviour (households) and corporate behaviour. However, according to Sørensen and Yosha's results (1998: 231-2) "personal saving contributes nothing to cross-country consumption smoothing", ${ }^{27}$ which implies that almost all of the reported private saving smoothing is the result of corporate net saving behaviour. $^{28}$

In order to estimate such effects, ASY98 methodology will be used. ASY98 were also only able to differentiate between two sectors because of data limitations. We start by remembering that the incremental smoothing provided by total net saving $\left(\beta_{\mathrm{s}}\right)$ is obtained by the regression:

$$
\Delta \log \mathrm{DNI}_{\mathrm{t}}^{\mathrm{i}}-\Delta \log \left(\mathrm{C}_{\mathrm{t}}^{\mathrm{i}}+\mathrm{G}_{\mathrm{t}}^{\mathrm{i}}\right)=\mathrm{v}_{\mathrm{s}, \mathrm{t}}+\beta_{\mathrm{s}} \Delta \log \mathrm{GDP}_{\mathrm{t}}^{\mathrm{i}}+\mathrm{u}_{\mathrm{s}, \mathrm{t}}^{\mathrm{i}}
$$

To break the smoothing provided by total net saving down further into private and government saving, we will use the following regression:

$$
\Delta \log \mathrm{DNI}_{\mathrm{t}}^{\mathrm{i}}-\Delta \log \left(\mathrm{DNI}_{\mathrm{t}}^{\mathrm{i}}-\mathrm{X}_{\mathrm{t}}^{\mathrm{i}}\right)=\mathrm{v}_{\mathrm{x}, \mathrm{t}}+\beta_{\mathrm{SX}} \Delta \log \mathrm{GDP}_{\mathrm{t}}^{\mathrm{i}}+\mathrm{u}_{\mathrm{x}, \mathrm{t}}^{\mathrm{i}}
$$

where the generic variable $\mathrm{X}$ is either net government saving or net private saving.

\footnotetext{
${ }^{27}$ SY98 were able to distinguish the three components of saving because they used a more restricted sample of 13 OECD countries for which detailed data was available.

${ }^{28}$ Later, this result will be used to compare our results with those obtained for the US states by ASY96. 
Table 3 - Decomposition of smoothing provided by total net saving into government and private sectors 1970-1999

\begin{tabular}{lcccccc}
\hline & All & \multirow{2}{*}{ EU15 } & \multirow{2}{*}{ EU12 } & Small & $\begin{array}{c}\text { Small } \\
\text { EU12 }\end{array}$ & $\begin{array}{c}\text { Small } \\
\text { EU15 }\end{array}$ \\
\hline Government & 29 & 27 & 21 & 25 & 18 & 26 \\
& $(7)$ & $(6)$ & $(4)$ & $(5)$ & $(3)$ & $(5)$ \\
Private & 21 & 24 & 32 & 28 & 37 & 26 \\
& $(4)$ & $(4)$ & $(4)$ & $(4)$ & $(4)$ & $(3)$ \\
Total saving $\left(\beta_{\mathrm{s}}\right)$ & 50 & 51 & 53 & 52 & 55 & 52 \\
& $(15)$ & $(12)$ & $(11)$ & $(12)$ & $(9)$ & $(10)$ \\
\multicolumn{7}{l}{ Notes: see notes to Table 2 for description of the samples of countries considered, and text for details. }
\end{tabular}

Table 3 presents the results. ${ }^{29}$ In general, the contribution made by the government sector to smoothing is larger than that of the private sector. For the whole OECD19 sample, the government sector is found to smooth $29 \%$ of the shocks for the period 1971-1999, while the private sector saving behaviour was responsible for $21 \%$ of smoothing. The figures for the EU15 are very similar (27\% and 24\%, respectively). For these countries, the government sector is responsible for more than $50 \%$ of the smoothing due to saving. Euro12 countries show, however, a different pattern of smoothing: the private sector $(32 \%)$ contributes more to smoothing than the government (21\%). The same pattern showing the predominance of private sector saving smoothing is also found in the small-country subsample, especially for the subset of small euro-area economies. For the latter, the gap between public and private smoothing through saving is the largest of all: the private sector saving smoothes $37 \%$ of the shocks while the government smoothes only $18 \%$. The lower degree of risk sharing through the government sector in small countries may be the result of the lower effectiveness of automatic fiscal stabilisers at smoothing output in relatively small economies (see Marinheiro (2003: Chapter 3)).

\subsection{Consumption smoothing: high vs. low deficit countries}

An attempt will now be made to answer the question regarding whether the contribution made by public sector saving to output smoothing is the same irrespective of government deficit. According to recent literature, the higher the budget deficit or the debt accumulation, the lower the effectiveness of fiscal stabilisers. ${ }^{30}$ In order to test this hypothesis it is necessary to distinguish high from low deficit countries. ${ }^{31}$ ASY98 propose to split the sample according to the average deficit over the sample period for each country. They found no evidence that the deficit level affects the amount of consumption smoothing provided by the public, or private, sectors (ASY98: 17). The reason for this lack of

\footnotetext{
${ }^{29}$ Following ASY98, no correction for first order serial correlations was made while estimating the government and private contributions as such a correction was considered to be unjustified.

${ }_{30}^{30}$ Just see for example Perotti (1999) and Artis and Buti (2000).

${ }^{31}$ A direct test regarding whether the level of public debt has any impact on the amount of risk sharing provided by the government sector was also carried out. The results obtained (but unreported here for brevity) are very similar to those obtained in this section.
} 
evidence is the difference in behaviour between the EU and OECD samples. While for the EU sample the authors concluded that the smoothing through the government sector is higher for low deficit countries, the conclusion is the opposite for the larger OECD group. For the OECD group ASY98 found more smoothing in high-deficit countries. However, it should be mentioned that in their applied work, ASY98 considered net government saving to be equal to the negative of the deficit (ASY98: 17). As a result, they rather imperfectly used net saving data to distinguish high from low deficit countries instead of using government net lending data. As can be seen by the formulae in Appendix A, these two measures are only equivalent when government net capital transfers and government consumption of fixed capital are equal to government gross capital formation and government purchases of land and intangible assets, i.e. when the capital budget balance is exactly the symmetric of government capital consumption. ${ }^{32}$

Table 4 - Decomposition of smoothing provided by total net saving into government and private sectors - high vs. low deficit countries -using ASY definition

\begin{tabular}{|c|c|c|c|c|c|c|c|c|c|c|c|c|}
\hline \multirow[b]{3}{*}{ Deficit level $\rightarrow$} & \multicolumn{6}{|c|}{ 1970-1999 } & \multicolumn{4}{|c|}{ 1980-1993 } & \multirow{2}{*}{\multicolumn{2}{|c|}{$\begin{array}{c}\text { 1986-1999 } \\
\text { All }\end{array}$}} \\
\hline & \multicolumn{2}{|c|}{ All } & \multicolumn{2}{|c|}{ EU15 } & \multicolumn{2}{|c|}{ Small } & \multicolumn{2}{|c|}{ All } & \multicolumn{2}{|c|}{$\begin{array}{c}\text { OECD17 } \\
\text { (SY98) }\end{array}$} & & \\
\hline & High & Low & High & Low & High & Low & High & Low & High & Low & High & Low \\
\hline \multirow[t]{2}{*}{ Governmt. } & 15 & 53 & 12 & 55 & 8 & 55 & 24 & 80 & 40 & 31 & 15 & 81 \\
\hline & (3) & (7) & (2) & (6) & (1) & (5) & (3) & (7) & (7) & (6) & (2) & (7) \\
\hline \multirow[t]{2}{*}{ Private } & 37 & 2 & 41 & -4 & 49 & -1 & 23 & -25 & 12 & 6 & 24 & -14 \\
\hline & (5) & $(0)$ & (5) & $(0)$ & (5) & $(0)$ & (2) & (2) & (2) & (2) & (2) & (1) \\
\hline Total & 52 & 54 & 54 & 51 & 56 & 54 & 47 & 55 & 52 & 37 & 39 & 67 \\
\hline Saving $\left(\beta_{\mathrm{s}}\right)$ & (11) & (12) & (9) & (9) & (9) & (9) & (7) & (7) & (10) & (6) & (5) & (9) \\
\hline
\end{tabular}

Notes: see notes to Table 2 for a description of the samples of countries considered. High deficit countries: those with an average deficit above the average deficit of the sample (2.76\%). Low deficit countries: Austria, Germany, Denmark, Finland, France, Japan, Norway, and Sweden. High deficit countries: Australia, Belgium, Canada, Spain, the U.K., Greece, Ireland, Italy, the Netherlands, Portugal, and the USA. The shaded columns regarding OECD17 are from SY98, table 3.9, page 32 .

In Table 4, the method proposed by ASY98 was used to distinguish such sub-groups (but using net governement lending data). That is, we considered "high deficit countries" to be those that showed, over the period 1970-1999, an average deficit above the unweighted average deficit of the whole sample, which was $2.76 \%$. As a result, our group of high deficit countries consisted of eleven countries (Australia, Belgium, Canada, Spain, the U.K., Greece, Ireland, Italy, the Netherlands, Portugal, and the USA), and the remaing eight countries consisted of the low deficit countries (Austria, Germany, Denmark, Finland, France, Japan, Norway, and Sweden).

\footnotetext{
${ }^{32}$ In other words, and neglecting net capital transfers, this assumption is only true when the amount of government net capital formation is nill. When considering the whole economy, as described by a Solow growth model, zero net capital formation (i.e., capital depreciation equal to capital formation) is only obtained when we assume that the economy is at a steady state with no technical progress and no population growth. These assumptions are very difficult to sustain in the case of industrialised countries, consequently ASY98's simplification might bias their empirical results.
} 
The empirical results lead clearly to the conclusion that a large government budget deficit has indeed a negative effect on the amount of consumption smoothing through government net saving. Both for the 19 OECD countries and the EU-15 economies, the consumption smoothing provided by the government sector is substantially higher for low deficit countries. For all 19 OECD economies, government saving smoothes $53 \%$ of the shocks for low deficit countries, while for high deficit countries the smoothing level is only of $15 \%$. Even during the ASY98 period of 1980-93, we found no evidence that for OECD countries the smoothing of shocks provided by the government sector is higher for high deficit countries. ${ }^{33}$ Another conclusion drawn from the results is that the amount of private and government smoothing appears to be substitute: the amount of total net saving smoothing does not differ considerably between high and low deficit countries. ${ }^{34}$ For low deficit countries, almost all the smoothing is provided by government saving behaviour, while for high deficit countries the major provider of consumption smoothing through saving is the private sector.

As for the small countries, they show the same pattern, with the exception of an unusually low contribution from the government sector net saving to smoothing in high deficit countries. It should be noted that all the Nordic countries along with Austria are included in the low-deficit-small-country subgroup. These are countries that have large fiscal stabilisers, which help to explain the high contribution made by the government sector in this subgroup.

Table 5 - Decomposition of smoothing provided by total net saving into government and private sectors- high vs. low deficit countries - using Deficit above/below average definition

\begin{tabular}{|c|c|c|c|c|c|c|c|c|c|c|}
\hline \multirow[b]{3}{*}{ Deficit level $\rightarrow$} & \multicolumn{6}{|c|}{ 1970-1999 } & \multirow{2}{*}{\multicolumn{2}{|c|}{$\frac{1980-1993}{\text { OECD }}$}} & \multirow{2}{*}{\multicolumn{2}{|c|}{$\frac{1986-1999}{\text { All }}$}} \\
\hline & \multicolumn{2}{|c|}{ All } & \multicolumn{2}{|c|}{ EU15 } & \multicolumn{2}{|c|}{ Small } & & & & \\
\hline & Above & Below & Above & Below & Above & Below & Above & Below & Above & Below \\
\hline \multirow[t]{2}{*}{ Governmt. } & 19 & 29 & 17 & 26 & 7 & 25 & 24 & 48 & 34 & 40 \\
\hline & (3) & (6) & (2) & (5) & (1) & (4) & (2) & (7) & (3) & (6) \\
\hline \multirow[t]{2}{*}{ Private } & 37 & 18 & 45 & 18 & 60 & 20 & 4 & 5 & -4 & 7 \\
\hline & (3) & (3) & (3) & (3) & (4) & (3) & (0) & (1) & (0) & (1) \\
\hline $\begin{array}{l}\text { Total saving } \\
\left(\beta_{\mathrm{s}}\right)\end{array}$ & $\begin{array}{l}56 \\
(8)\end{array}$ & $\begin{array}{r}46 \\
(13)\end{array}$ & $\begin{array}{l}62 \\
(8)\end{array}$ & $\begin{array}{l}44 \\
(9)\end{array}$ & $\begin{array}{l}67 \\
(7)\end{array}$ & $\begin{array}{l}45 \\
(9)\end{array}$ & $\begin{array}{l}28 \\
(3)\end{array}$ & $\begin{array}{c}53 \\
(10)\end{array}$ & $\begin{array}{l}31 \\
(4)\end{array}$ & $\begin{array}{l}47 \\
(9)\end{array}$ \\
\hline
\end{tabular}

Notes: see notes to Table 2 for a description of the samples of countries considered. Each year a country is classified as being a high deficit country if its government budget deficit surpasses the (unweighed) average deficit of the whole sample of 19 OECD economies by at least $1 \%$.

In Table 5, another method was used to distinguish low-deficit from high-deficit sub-samples i.e. the classification of countries was allowed to vary over time. Each year a country was considered as having a large deficit if its deficit level was substantially above

\footnotetext{
${ }^{33}$ To aid comparison, Table 4 also includes the ASY98 results for the OECD17 group.

${ }^{34}$ In general, the amount of smoothing provided by the private sector is not statistically different from zero for low-deficit countries.
} 
the (unweighted) average budget deficits of the aggregate OECD19 recorded in that year. More precisely, a country was classified as having an 'above normal' deficit in year $\mathrm{t}$, when its budget deficit for that period was larger than the average OECD deficit by at least $1 \%$. Deficits were defined as 'below' in all other cases.

The empirical results show that the sample of 'below average' deficit benefits from a larger (and statistically significant) contribution from government saving to output smoothing. This result underscores the previous conclusion that a high deficit leads to a reduction in the amount of smoothing provided by net government saving. Again it was found that for small countries, an 'above normal' deficit results in a very small contribution from the government sector to the smoothing of consumption shocks. ${ }^{35}$ However, an increase in the contribution of the private sector more than compensates for this decrease. For the whole period 1970-1999, it was found that the 'above-average' deficit sub-sample displayed a higher amount of total smoothing provided by saving. However, this somewhat unexpected result does not hold for the 1980-1993 nor for the 1986-1999 subperiods.

\subsection{Comparison with the states of the USA}

It is very interesting to compare the results obtained for our group of countries with those obtained for the states of the USA by Asdrubali et al. (1996), hereafter referred to as ASY96. In order to do so, it will be necessary aggregate our more detailed results into three levels of smoothing: capital market, transfers and credit market. Capital market smoothing corresponds to the sum of factor income, capital depreciation, and corporate saving smoothing. Using Sørensen and Yosha's conclusion (1998: 231-2) on the non-relevance of personal saving, our estimate assumes that the amount of personal saving smoothing is nil. Transfers refer to international transfer smoothing. Credit market smoothing corresponds to smoothing through both personal and government saving.

Table 6 shows both the SY98 estimates and our own for the period 1981-1990. The results for our sample of 19 OECD economies are relatively close to those of SY98, which related to their more restricted sample of 12 OECD countries: the amount of unsmoothed shocks was found to be similar (62\% in our estimate, $57 \%$ in the SY98 sample). However, the smoothing by capital markets was higher in the SY98 estimates (15\% compared with $8 \%$ for our sample of countries), and the results for the EU countries were substantially different from those reported in SY98. The unusually low level of credit market smoothing reported by SY98 for their six EU countries (3\%) was not found with our sample of EU15 economies. Our estimate was much closer to the result reported for the OECD (19\%). Nevertheless, both in our own estimate and in that of SY98, when the OECD and the EU samples are compared, the latter displays a much lower level of smoothing provided by the credit market, which in turn implies a larger amount of unsmoothed shocks. These differences in the smoothing due to the credit market channel are the result of the different government contributions made to smoothing. They may also reflect differences in the

\footnotetext{
${ }^{35}$ This contribution is not statistically different from zero. 
relative importance of the banking sector, and in particular variations in relationship lending between Continental Europe and the Anglo-Saxon world.

Table 6 - Comparison of income and consumption smoothing: EU, OECD, and US States - SY98 and our own results for the period 1981-1990

\begin{tabular}{lccccccc}
\hline & \multicolumn{3}{c}{ SY98 } & & \multicolumn{2}{c}{ Own estimate } \\
\cline { 2 - 4 } \cline { 6 - 7 } \cline { 6 - 7 } & US states & OECD* & EC6 & & All & EU15 \\
\hline Capital markets & 48 & 15 & 8 & & 8 & 9 \\
& $(12)$ & $(4)$ & $(1)$ & & $(0)$ & $(0)$ \\
Transfers & 14 & 2 & 7 & & 3 & 5 \\
& $(14)$ & $(2)$ & $(2)$ & & $(2)$ & $(2)$ \\
Credit market & 19 & 26 & 3 & & 27 & 19 \\
& $(2)$ & $(5)$ & $(0)$ & & $(4)$ & $(2)$ \\
Not smoothed & 19 & 57 & 82 & & 62 & 68 \\
& $(2)$ & $(11)$ & $(9)$ & & $(11)$ & $(8)$
\end{tabular}

Notes: see notes to Table 2 for a description of the samples of countries considered. The source of the first three columns is ASY96, table 1, page 1092. EC6: Belgium, Denmark, Finland, France, Germany, Italy, and UK. OECD*: Austria, Belgium, Finland, France, Germany, Italy, Sweden, UK, USA, Japan, Australia, and Canada. ASY96 report standard errors in their tables, thus the corresponding T-stats for ASY96 were obtained by dividing the coefficient estimate by its standard deviation, ignoring any (non-reported) rescaling. Capital markets smoothing corresponds to the sum of factor income, capital depreciation, and corporate saving smoothing. Transfers refer to international transfer smoothing. Credit market smoothing corresponds to smoothing through personal and government saving. Our estimate assumes that the amount of personal saving smoothing is nil.

Comparing the results for the US states with those of our estimates for the EU15, for the period 1981-1990, it can be seen that the amount of shocks left unsmoothed is much higher in the EU than within the US federation (68\% compared with only $19 \%$ ). This is mainly the result of the enormous difference in the amount of smoothing provided by the capital markets. Capital markets smooth $48 \%$ of asymmetric shocks to the US states GSP, while in the EU they only smooth $9 \%$ of the idiosyncratic shocks to GDP. ${ }^{36}$ The role of the US federal tax-transfer system at smoothing output (14\%) is also considerably higher than the contribution of international transfers to smoothing shocks to EU output (5\%). Interestingly, the amount smoothed by the credit market is exactly the same in both estimates (19\%). ${ }^{37}$ As the credit market smoothing mainly measures the smoothing provided by government saving behaviour, it can be concluded that the public sector plays a crucial role in the smoothing of asymmetric shocks in Europe. Sørensen and Yosha (1998) go even further and conclude that the restrictions on national budget deficits imposed by the European Union Treaty should be relaxed to allow governments to smooth output shocks. They further maintain that a greater insurance role for the EU budget may be

\footnotetext{
${ }^{36}$ Moreover, the amount of capital market smoothing is not statistically different from zero for the EU, while it is highly statistically significant for the US states.

${ }^{37}$ Both such estimates present a T-statistic of 2.
} 
demanded by national governments, until the degree of integration of the EU credit market allows a substantial amount of consumption smoothing via personal saving. ${ }^{38}$

Table 7 - Comparison of income and consumption smoothing: EU, OECD, and US States 1970-1999

\begin{tabular}{|c|c|c|c|c|c|c|c|c|c|}
\hline & $\begin{array}{c}\text { US } \\
\text { states } \\
1964-90\end{array}$ & $\begin{array}{c}\text { US } \\
\text { states } \\
1981-90\end{array}$ & $\begin{array}{c}\text { US } \\
\text { states } \\
1970-98\end{array}$ & All & EU15 & EU12 & Small & $\begin{array}{l}\text { Small } \\
\text { EU12 }\end{array}$ & $\begin{array}{l}\text { Small } \\
\text { EU15 }\end{array}$ \\
\hline $\begin{array}{l}\text { Capital } \\
\text { markets }\end{array}$ & $\begin{array}{l}39 \\
(13)\end{array}$ & $\begin{array}{l}48 \\
(12)\end{array}$ & $\begin{array}{c}45 \\
(17)\end{array}$ & $\begin{array}{l}12 \\
\text { (3) }\end{array}$ & $\begin{array}{l}15 \\
(3)\end{array}$ & $\begin{array}{l}25 \\
(3)\end{array}$ & $\begin{array}{l}19 \\
(3)\end{array}$ & $\begin{array}{l}30 \\
(4)\end{array}$ & $\begin{array}{l}18 \\
(3)\end{array}$ \\
\hline Transfers & $\begin{array}{c}13 \\
(13)\end{array}$ & $\begin{array}{c}14 \\
(14)\end{array}$ & $\begin{array}{c}14 \\
(35)\end{array}$ & $\begin{array}{l}-1 \\
(1)\end{array}$ & $\begin{array}{l}-1 \\
(1)\end{array}$ & $\begin{array}{l}-2 \\
(2)\end{array}$ & $\begin{array}{l}-2 \\
(2)\end{array}$ & $\begin{array}{l}-3 \\
(2)\end{array}$ & $\begin{array}{l}-3 \\
(2)\end{array}$ \\
\hline Credit market & $\begin{array}{l}23 \\
(4)\end{array}$ & $\begin{array}{l}19 \\
(2)\end{array}$ & $\begin{array}{l}21 \\
(4)\end{array}$ & $\begin{array}{l}29 \\
(7)\end{array}$ & $\begin{array}{l}27 \\
(6)\end{array}$ & $\begin{array}{l}21 \\
(4)\end{array}$ & $\begin{array}{l}25 \\
(5)\end{array}$ & $\begin{array}{l}18 \\
(3)\end{array}$ & $\begin{array}{c}26 \\
(5)\end{array}$ \\
\hline $\begin{array}{l}\text { Not } \\
\text { smoothed }\end{array}$ & $\begin{array}{l}25 \\
(4)\end{array}$ & $\begin{array}{l}19 \\
(2)\end{array}$ & $\begin{array}{l}20 \\
(4)\end{array}$ & $\begin{array}{l}59 \\
(20)\end{array}$ & $\begin{array}{l}59 \\
(16)\end{array}$ & $\begin{array}{l}56 \\
(13)\end{array}$ & $\begin{array}{c}59 \\
(16)\end{array}$ & $\begin{array}{l}55 \\
(11)\end{array}$ & $\begin{array}{l}59 \\
(14)\end{array}$ \\
\hline
\end{tabular}

Notes: see notes to Table 2 for a description of the samples of countries considered. T-statistics are given in brackets. The source of the two columns is ASY96, table I and table III (pages 1092 and 1094). ASY96 report standard errors in their tables, thus the corresponding T-stats for ASY96 were obtained by dividing the coefficient estimate by its standard deviation, ignoring any (non-reported) rescaling. The third column for the US, is obtained by using Bent Sørensen's database and his econometric program. Capital market smoothing corresponds to the sum of factor income, capital depreciation, and corporate saving smoothing. Transfers refers to international transfer smoothing. Credit market smoothing corresponds to smoothing through personal saving and government saving. Our estimate assumes that the amount of personal saving smoothing is nil.

Table 7 shows our estimates for the full 1970-1999 period together with ASY96's results for the US states for the periods 1964-1970 and 1981-1990. We included as well, updated estimates for the US states for the period 1970-1998. These estimates were obtained by using Bent Sørensen's database and econometric program.

For the period 1970-1999, our results relative to the three channels of smoothing do not vary substantially for the different subsamples of countries considered. In the OECD, the most important channel of output smoothing is the credit market (it represents $29 \%$ of smoothing achieved by the 19 OECD economies). ${ }^{39}$ Next in importance, comes the capital market smoothing (12\% for the same group). International transfers actually dis-smooth output (-1\% for OECD19), but are not statistically different from zero. ${ }^{40}$ As in Table 2, the

\footnotetext{
38 More recently, Kalemli-Ozcan, Sørensen and Yosha (2003) updated the SY98 and ASY98 estimates. However, the new results are not directly comparable to previous ones as the authors changed the estimation method and limited their study to just the first channel of output smoothing, i.e., the smoothing that occurs through factor income. They found that factor income makes a positive contribution to smoothing in the more recent period of 1993-2000. More precisely, factor income was found to smooth $6 \%$ of the shocks to GDP in the EU-14 countries [11\% in the former EU8], which compares with $55 \%$ in the US states. This partial analysis led the authors to change their previous conclusions of SY98 to state that “... the unified Europe is becoming more similar to the union of US states in terms of integration at the macroeconomic level!" (idem, p. 2). In our opinion, this conclusion might be rushed since it is based on just one channel of smoothing (disregarding the total amount of unsmoothed shocks), and on a very short period of time.

39 It should be remembered that the credit market channel corresponds to the smoothing achieved via government net saving.

${ }^{40}$ When comparing the t-statistics of the ASY96 estimates for the US states, and our own estimates for OECD countries we can see that for the US states the capital market smoothing and transfers have been estimated
} 
amount of shocks left unsmoothed is around $60 \%$ for the several subsamples considered. Comparing the small countries with the enlarged group of 19 OECD economies, the former shows a higher degree of smoothing through the capital markets (19\%), and a somewhat lower smoothing through the credit market (25\%). Overall, the amount of shocks smoothed by the three channels is roughly the same, being the amount of shocks left unsmoothed $(59 \%)$ for both groups of countries. The small euro-area economies display a similar picture to the more extended sample of small OECD countries, showing, however, a higher degree of capital market smoothing (30\%) and a lower smoothing through the credit market. Adding the $3 \%$ of dis-smoothing provided by the international transfers, we arrive at a total of $55 \%$ of shocks left unsmoothed.

As for the twelve euro-area legacy countries, they show a level of capital market smoothing of $25 \%$, which is higher by 13 percentage points (p.p.) than in the OECD19. However, the degree of risk sharing provided by the credit market $(21 \%)$ is 8 p.p. below the figure for the whole sample. As a result, the total amount of unsmoothed shocks is $56 \%$, only 3 percentage points below the figure for the whole sample of 19 OECD economies. Consequently, from the viewpoint of cross-country risk sharing, it appears that before the period of introduction of the euro (1999), the euro-area economies were not substantially better prepared to embrace monetary union than the rest of the OECD countries considered in our study.

According to our results, an eventual enlargement of the euro zone to include the UK, Denmark, and Sweden, i.e. to all EU-15 members, will lead to a small increase in the amount of unsmoothed shocks (3 p.p.). This is the result of a smaller capital market contribution to smoothing in these three 'non-participating' countries (the difference between EU-15 and EU-12 is -10 p.p.), which is not fully compensated for by higher credit market smoothing, i.e. government led smoothing ( +6 p.p.).

Comparing the euro-area with the federation of the USA, it can be seen that the amount of total risk sharing is considerably lower in the former group of countries, where the amount of shocks left unsmoothed is $56 \%$, which compares with only $20 \%$ for the US. With regard to the different channels of risk sharing, the credit market smoothing in the EU12 countries (21\%) exactly the same amount of its equivalent in the US (in the 19701998 period). However, the main differences between the two regions are the amount of risk sharing provided by transfers and by the capital markets. While in the US the federal government tax and transfers system smoothes $14 \%$ of the idiosyncratic regional shocks, in the EU12 such an inter-regional transfer system does not exist. The international transfers actually dis-smooth output by $2 \%$. The amount of risk sharing provided by the capital markets in the euro-area legacy countries (25\%) is also substantially below (approximately just half) that of the US states (45\% for the period 1970-1998, and 48\% for 1981-1990).

precisely, while for our sample of international countries higher standard deviations were found. Conversely, our estimates for the credit market channel and for the total amount of unsmoothed shocks show much lower standard deviations than ASY96's estimates for the US states. A similar pattern is apparent in the SY98 estimates (see Table 6). 
This is most probably the result of a much lower degree of cross-country ownership of productive assets than in the monetary union of the United States.

If, due to the introduction of the euro, capital markets become as integrated in the euro-area as they were in the US federation in the 1970-1998 period, an increase of 20 p.p. in the amount of risk sharing provided by euro-area capital markets could be expected. Everything else constant, the amount of shocks unsmoothed is expected to drop to $36 \%$ in this scenario. However, the total amount of shocks left unsmoothed in the euro-area would still be considerably larger than the $20 \%$ found in the US states, due to the lack of smoothing through international transfers in the euro-area. A larger EU central budget might help in this regard. However, it could also be argued that the Stability and Growth Pact dispositions, which constrain the operation of fiscal policy within the EMU, might lead to a reduction of the amount of smoothing provided by the credit markets, which is mainly the result of government net saving smoothing.

\subsection{More persistent shocks}

It is also interesting to observe what happens when the length of the differencing frequency interval is increased from one to three years. ${ }^{41}$ Such an increase in the differencing interval allows an analysis of the response of the economy to more longlasting shocks to be made. Table 8 shows the results obtained.

Table 8- Channels of income and consumption spending (\%)- 3 years differencing interval

\begin{tabular}{lccccc}
\hline & All & Small & EU15 & EU12 & Small \\
& -5 & -5 & -5 & -4 & -4 \\
\hline Factor income $\left(\beta_{\mathrm{f}}\right)$ & $(4)$ & $(3)$ & $(3)$ & $(2)$ & $(2)$ \\
& -5 & -4 & -4 & -4 & -4 \\
Capital Depreciation $\left(\beta_{\mathrm{d}}\right)$ & $(4)$ & $(3)$ & $(3)$ & $(3)$ & $(3)$ \\
& 1 & 0 & 0 & 0 & -1 \\
International & $(1)$ & $(0)$ & $(0)$ & $(0)$ & $(1)$ \\
Transfers $\left(\beta_{\mathrm{t}}\right)$ & 35 & 37 & 34 & 37 & 41 \\
Saving $\left(\beta_{\mathrm{s}}\right)$ & $(11)$ & $(9)$ & $(9)$ & $(8)$ & $(7)$ \\
& 33 & 30 & 31 & 25 & 23 \\
$\quad$ - Of which government & $(10)$ & $(7)$ & $(8)$ & $(7)$ & $(5)$ \\
$\quad$ & 2 & 6 & 3 & 12 & 18 \\
$\quad$ Of which private & $(0)$ & $(1)$ & $(1)$ & $(2)$ & $(3)$ \\
Not Smoothed $\left(\beta_{\mathrm{u}}\right)$ & 74 & 72 & 74 & 71 & 68 \\
& $(28)$ & $(21)$ & $(22)$ & $(18)$ & $(14)$ \\
\hline
\end{tabular}

Notes: see notes to Table 2 for a description of the samples of countries considered. Results obtained without correcting for serial correlation.

\footnotetext{
${ }^{41}$ For example, the variation of GDP is now defined as $\left(\mathrm{GDP}_{\mathrm{t}}-\mathrm{GDP}_{\mathrm{t}-3}\right)$. 
When the differencing frequency is increased to three years, the amount of longlasting, unsmoothed shocks increases considerably: almost $3 / 4$ of all shocks remain unsmoothed (across the whole sample this value increases from 59\% to 74\%). Now both factor income and capital depreciation dis-smooth output, and international transfers are more or less irrelevant within this time scale. The latter contribution is almost nil and is not statistically different from zero. The only operative channel for smoothing output is net saving. For the whole sample of 19 OECD countries, saving smoothes $35 \%$ of all shocks at the 3 years horizon. When we previously considered shocks that lasted for just one year, i.e. at the one year differencing frequency interval, this value was much higher (50\%).

Taking this further by subdividing the contribution from total net saving into public and private components, we reach the very interesting conclusion that at the 3 -year horizon, the smoothing effect of saving is almost exclusively due to the public sector (33\%) while private saving contributes almost nothing to risk sharing (2\%). As mentioned above, at the one-year differencing frequency interval the contribution from both sectors were more or less balanced, with a slight prominence coming from the public sector. Hence, when dealing with more persistent shocks only government saving appears to be effective at providing risk sharing. However, the contribution of private sector saving to risk sharing is comparatively more important in the case of small countries $(6 \%)$ and is especially so for the euro-area economies (12\%).

A possible explanation for this is that, according to the results of SY98, the contribution to smoothing from private saving is mainly the result of corporate saving behaviour. Since corporations do not make final consumption expenditures, the net saving of corporations must be equal to their net disposable income. ${ }^{42}$ In other words, corporation savings correspond to retained earnings. Consequently, our results show that when a negative shock only lasts for a period, corporations are able to reduce the amount of retained earnings in order to maintain the amount of distribution of dividends (increasing the payout ratio), thus helping to stabilise shareholders' income. In order to do so the corporations may also have to resort to increasing external finance. This is because the operating surplus (and profits) are negatively affected by the shock on GDP and some expenditure, namely employee compensation and investment plans, may not be immediately adjusted (i.e., downgraded). However, this reaction on the part of corporations is not sustainable when a negative shock lasts over a longer period. Only the government sector has the ability to resort to debt in order to sustain the decrease in net savings over such a longer period of time.

\footnotetext{
42 See Commission of the European Communities/Eurostat, Imf, Oecd et al. (1993: paragraph 9.4). 


\subsection{Evolution of smoothing patterns over time}

Table 9- Channels of income and consumption spending (\%) -evolution over time

\begin{tabular}{|c|c|c|c|c|c|c|c|c|c|}
\hline & \multicolumn{3}{|c|}{ All } & \multicolumn{3}{|c|}{ EU15 } & \multicolumn{3}{|c|}{ EU12 } \\
\hline & $\begin{array}{c}1971- \\
85 \\
\end{array}$ & $\begin{array}{c}1986- \\
99 \\
\end{array}$ & $\begin{array}{c}\text { 1971- } \\
99 \\
\end{array}$ & $\begin{array}{c}1971- \\
85 \\
\end{array}$ & $\begin{array}{c}1986- \\
99 \\
\end{array}$ & $\begin{array}{l}\text { 1971- } \\
99\end{array}$ & $\begin{array}{l}1971- \\
85 \\
\end{array}$ & $\begin{array}{c}1986- \\
99\end{array}$ & $\begin{array}{l}\text { 1971- } \\
99\end{array}$ \\
\hline \multirow[t]{2}{*}{ Factor income $\left(\beta_{\mathrm{f}}\right)$} & -1 & -3 & -2 & -1 & -2 & -1 & 0 & -1 & 0 \\
\hline & (1) & (1) & (1) & (1) & (1) & (1) & (0) & (1) & (0) \\
\hline \multirow{2}{*}{$\begin{array}{l}\text { Capital Depreciation } \\
\left(\beta_{d}\right)\end{array}$} & -7 & -8 & -7 & -8 & -7 & -7 & -7 & -7 & -7 \\
\hline & (5) & (4) & (7) & (5) & (3) & (6) & (4) & (3) & (6) \\
\hline International & -2 & 2 & -1 & -3 & 2 & -1 & -4 & 2 & -2 \\
\hline Transfers $\left(\beta_{t}\right)$ & (2) & (2) & (1) & (2) & (1) & (1) & (2) & (1) & (2) \\
\hline \multirow[t]{2}{*}{ Saving $\left(\beta_{\mathrm{s}}\right)$} & 52 & 49 & 50 & 54 & 46 & 51 & 56 & 51 & 53 \\
\hline & (11) & (9) & (15) & (9) & (7) & (12) & (8) & (6) & (11) \\
\hline \multirow{2}{*}{$\begin{array}{l}\text {-Of which } \\
\text { government }\end{array}$} & 17 & 46 & 29 & 15 & 43 & 27 & 10 & 37 & 21 \\
\hline & (3) & (7) & (7) & (3) & (5) & (6) & (2) & (4) & (4) \\
\hline \multirow[t]{2}{*}{-Of which private } & 35 & 3 & 21 & 39 & 2 & 24 & 46 & 15 & 32 \\
\hline & (5) & (0) & (4) & (5) & (0) & (4) & (5) & (1) & (4) \\
\hline \multirow[t]{2}{*}{ Not Smoothed $\left(\beta_{\mathrm{u}}\right)$} & 58 & 60 & 59 & 58 & 61 & 59 & 56 & 54 & 56 \\
\hline & (13) & (15) & (20) & (10) & (12) & (16) & (8) & (9) & (13) \\
\hline
\end{tabular}

Notes: see notes to Table 2 for description of the samples of countries considered.

The evolution of the pattern of consumption smoothing over time will now be analysed. In Table 9 two sub-periods (1970-85 and 1986-99) can be recognised. Over these two subperiods, it can be seen that the major channels of risk sharing show great stability across the whole set of 19 countries: factor income contributes negatively to smoothing, increasing the dis-smoothing from $-1 \%$ to $-3 \%$; capital depreciation also contributes negatively to smoothing (varying from $-7 \%$ to $-8 \%$ ); the smoothing provided by saving is around $50 \%$; and the amount left unsmoothed varies from $58 \%$ to $60 \%$. On the contrary, the contribution to smoothing from international transfers varies within the sub-periods: for the first sub-period it contributes negatively to smoothing $(-2 \%)$, but in the more recent period of 1986-99 it contributes in a more modest but nonetheless positive way to smoothing $(+2 \%)$. Notwithstanding this general regularity, a closer look at the two subcomponents of total savings reveals substantial changes over time. For all 19 OECD economies, the contribution from private saving decreases considerably from the first to the second period (from $35 \%$ to $3 \%$ ). Such a decline is compensated for by a substantial increase in the contribution to risk sharing from government saving, which increases from $17 \%$ to $46 \%$. Thus, while the aggregated contribution of saving remains roughly the same, its composition differs radically between both sub-periods. 
The pattern observed for the EU15 countries does not differ significantly from that of the 19 OECD economies. However, the euro-area countries differ from the aggregated OECD pattern by showing a less pronounced decrease in the contribution to smoothing from private saving from the first to the second sub-periods considered: for the period 1986-99 the net private saving contribution to smoothing drops to $15 \%$ in EU12. Notwithstanding these less clear results for the euro-area, the instability in the subcomponents of saving led us to analyse the pattern of time evolution in more detail.

In Table 10 (Appendix B), we distinguish between 3 sub-periods at the cost of decreasing the number of degrees of freedom i.e. 1971-79, 1980-89, and 1990-99. Nevertheless, the number of degrees of freedom is still large. By analysing the evolution of the two subcomponents of saving, it can be seen that the aforementioned low value for the private saving contribution to smoothing in the 1986-99 period is due to the 1980s. For the whole sample of OECD countries, the private saving contribution in the 1970s was relatively large (42\%); in the 1980 s this positive contribution became almost non-existent (2\%); and, finally it regained some of its importance in the 1990s (12\%). The government saving contribution to risk sharing increased considerably and systematically over time (from $11 \%$ in the 1970 s, to $39 \%$ in the $1980 \mathrm{~s}$, and finally to $45 \%$ in the $1990 \mathrm{~s}$ ). The same evolution is also present in the EU12 sub-sample. Due to this pattern, the contribution of total saving for smoothing decreases considerably in the 1980s. As this decrease is not compensated for by positive changes in the other main components, whose contribution remains roughly unaltered, this ultimately leads to an increase in the amount of unsmoothed shocks in the 1980s. The recovery in government saving smoothing in the 1990s gives rise to an important decrease in the amount of shocks to GDP left unsmoothed in that period.

At the cost of another reduction in the degrees of freedom, Table 11 (Appendix B) goes a step further in the subdivision of the sample period: we now consider a half-decade subdivision. ${ }^{43}$ This subdivision enables us to conclude that the decrease in the amount of shocks left unsmoothed in the 1990s for the euro area is largely the result of an unusually high smoothing effect provided by the government saving in the first half of the 1990s (67\%). However, the contribution to smoothing of the government sector decreases considerably (to just 13\%) in the 1995-1999 period. This was probably due to fiscal tightening in the run-up to EMU.

This detailed subdivision also shows an interesting evolution of the factor income contribution to smoothing in the euro-area countries. Namely, there was a high instability of this parameter in the 1990s. The first half of the decade was characterized by an unusually high negative contribution of this factor $(-14 \%)$. As mentioned above, this could be related to the impact of the collapse of the USSR on Nordic-countries trade, and with the effects of German reunification and the EMS crisis (vide page 9). Conversely, in the second half of the 1990s, factor income flows are found to contribute positively to smoothing in the

\footnotetext{
${ }^{43}$ There is also a reduction in the precision of parameter estimates probably as a result of the reduction in the degrees of freedom. In spite of this, we still believe it to be a worthwhile exercise.
}

G.E.M.F. - F.E.U.C. 
EU-12 (17\%). One could interpret this result as giving an indication that the crossownerships of assets in the EU is increasing and already giving a large contribution to the smoothing of asymmetric shocks in output. ${ }^{44}$ However, in our view, it is not possible to draw such a conclusion from our results. As the $\beta_{\mathrm{f}}$ parameter revealed such a large instability in the nineties, it is not at all possible to claim, based on only one-half a decade sub-period, that this positive contribution will continue to be present in the near future. Moreover, our results show also that, even in the more recent period $1995-1999,53 \%$ of the idiosyncratic shocks to output remain unsmoothed in the euro-area legacy countries, which is still 2.8 times more than in the US states for the period 1981-1990 (19\%), and 5.9 times more than in the US for the comparable period 1995-1998 (9\%). ${ }^{45}$

\section{4- Conclusions}

We have presented empirical results regarding the patterns of risk sharing for a sample of 19 OECD economies, which includes all EU-15 member countries (except Luxembourg), for the period 1970-1999, i.e., for the thee decades running up to the introduction of the euro. Following Sørensen and Yosha (1998), we identified four channels of risk sharing: factor income flows, capital depreciation, international transfers and saving. We concluded that the only operative smoothing channel is saving. Total net saving was found to smooth $50 \%$ of the idiosyncratic shocks to GDP in our 19 OECD economies, while $59 \%$ of the shocks remained unsmoothed, i.e. causing a shock in consumption. Such amount of shocks left unsmoothed is considerably higher than the $25 \%$ found for the US states by Asdrubali et al. (1996), for the period 1964-1990.

With regard to the question of knowing whether euro-area countries were better prepared than the rest of the OECD economies considered, no substantial differences in the pattern of risk sharing among our different subsets of small, EU-15, and EU-12 economies were found. The amount of idiosyncratic shocks to GDP left unsmoothed in the Euroland was $56 \%$, which is very similar to the figure for the whole sample of OECD countries (59\%). Hence, we can conclude that, from the risk-sharing point of view, the euro-legacy countries do not appear to be better prepared to engage in a monetary union than the rest of the other OECD countries. Moreover, as in the OECD, only saving contributes positively to smoothing in the euro-area.

As the contribution from saving to smoothing may be divided into government and private components, it is possible to evaluate whether the private sector can substitute the government sector in providing output smoothing. We have concluded that for the whole sample of OECD countries the government sector contributed more to risk sharing $(29 \%)$ than the private sector (21\%). However, both small countries and the EU12 countries, and

\footnotetext{
${ }^{44}$ Just see Kalemli-Ozcan et al. (2003) and our comments on footnote 38 (on page 18).

${ }^{45}$ By using Prof. Bent Sørensen's econometric program for the US states, we found that only $9 \%$ of the interregional asymmetric shocks were left unsmoothed in the US for the period 1995-1998. The amount of smoothing due to the capital market was found to be $48 \%$; the transfers smoothed another $11 \%$ of shocks; and the credit market another $31 \%$.
} 
especially the small EU12 member states, show a contribution to risk sharing from the private sector which is higher than that of the government sector. In the case of small countries, this result may reflect the reduced effectiveness of automatic fiscal stabilisers. Although the contribution from the private sector in euro-area (32\%) is larger than that of the government $(21 \%)$, the contribution from the government is still decisive, especially in smoothing more persistent shocks to output. Moreover, as we will argue below, the smoothing due to government saving is not likely to be easily replaced by private capital markets in the near future.

However, fiscal profligacy was found to reduce the contribution to smoothing from the public sector. When high and low deficit countries were considered separately it was found, contrary to Arreaza et al. (1998), that there was clear evidence in favour of the hypothesis that a high deficit level leads to reduced consumption smoothing by the public sector. Such results lead us to conclude that in a successful monetary union it is vital to ensure there is enough short-time flexibility in the fiscal policy, while at the same time not disregarding fiscal discipline in the medium/long-term.

We compared as well our results for OECD and EU countries with those of Asdrubali et al. (1996) for the US states. According to their updated estimates, for the period 19701998 in the US states, only $20 \%$ of idiosyncratic shocks were left unsmoothed. Their results further show that insurance, i.e. capital market smoothing (45\%), is much more important than credit $(21 \%)$ in smoothing regional shocks in the USA. However, the credit channel itself is more important than the net transfers from the central federal government (14\%). For the EU12 countries, in the period 1970-1999, capital market insurance was found to smooth $25 \%$ of the shocks to GDP; the credit markets (essentially government net saving) smoothed another $21 \%$, while the international transfers actually dis-smoothed output $(-2 \%)$. As a result, $56 \%$ of the asymmetric shocks went unsmoothed. Hence, when comparing the US federation with the euro-legacy countries, some major differences emerge. Firstly, the amount of inter-regional shocks left unsmoothed in the euro-area $(56 \%)$ is more than twice the equivalent amount in the US federation (20\%). A second major difference between the EU12 and the US is that in the latter there is substantial interregional smoothing through the federal government deficit (14\%). This is absent in the euro legacy countries, where there is almost no inter-national smoothing through the EU central budget (international transfers were found to actually dis-smooth output by $-2 \%$ ). In contrast, the national governments budgets are found to have a decisive smoothing importance in the EU12. However, the national budgets provide mainly inter-temporal smoothing and not directly inter-regional smoothing. Thirdly, the amount of risk sharing provided by the capital markets in the EU12 is lower (25\%) than in the US (45\%). This lower insurance role is probably the result of the less-regionally diversified portfolios of assets among the residents of EU countries in comparison with their US counterparts. ${ }^{46}$

\footnotetext{
${ }^{46}$ Although the comparison of the euro-area with the US enables us to see some very interesting insights, we should mention that this comparison is not perfect. There is, in fact, a little asymmetry in the comparison between both regions due to the different methods used to reach the results for the US and for the EU. For the 
More smoothing is to be expected from market forces due to the functioning of EMU. EMU makes it is easier for countries to borrow internationally (before the introduction of the euro it was easier for individuals to borrow from within their own country than for countries to borrow from the rest of the world). In the long run, economic integration favours the holding of property claims across borders, i.e. it favours the cross-ownership of productive assets. If, due to the introduction of the euro, capital markets become as integrated in the euro-area as they were in the US federation in 1964-1990, we could expect a gain of 20 p.p. in the amount of risk sharing provided by euro-area capital markets. Holding everything else constant, the amount of shocks left unsmoothed is expected to drop to $36 \%$ under this (optimistic) scenario, which is still considerably larger than the $20 \%$ left unsmoothed in the US states. A possible explanation for this result is the already mentioned lack of smoothing through international transfers in the euro-area. Therefore, a larger EU central budget, with objectives other than the redistribution of structural funds, might help in this regard. It is also possible to argue that the constraints imposed by the Treaty and the Stability and Growth Pact (SGP) in the operation of fiscal policy in EMU, might lead to a reduction in the amount of smoothing provided by the credit markets, which is mainly the result of government net saving smoothing. Some SGP partisans argue that if member countries achieve a balanced budget position over the business cycle, the stability pact provides sufficient room-for-manoeuvre. However, this still remains to be proved in practice and is a source of concern.

Another considerable difference between the Euro-area and the US States is the way in which such two economic areas react to more persistent shocks. When the differencing frequency period is increased to three years, the amount of long-lasting unsmoothed shocks for the euro-area increases considerably: almost $3 / 4$ of all shocks remain unsmoothed. In the US States the increase in the amount of shocks left unsmoothed is much smaller (ranging from $25 \%$ to $34 \%$ ), reflecting the decrease in the smoothing provided by credit markets ($16 \%$ ) that is not compensated for by increases in capital markets $(5 \%)$ or by federal government smoothing (3\%). ${ }^{47}$ In contrast, in Europe the only operative channel for smoothing output is net saving (37\%). Furthermore, the smoothing effect of saving is almost exclusively due to the public sector (25\%). Consequently, in our opinion, limitations on the use of fiscal policy that induce a reduction in the amount of stabilisation provided by the government could have negative consequences for EU-12 economies.

According to our results, an eventual enlargement of the euro zone to include the UK, Denmark, and Sweden, i.e. to all EU-15 members, would lead to a small increase in the amount of shocks left unsmoothed (3 p.p.). This would be the result of a smaller capital market contribution to smoothing in those three 'out' countries (the difference between EU15 and EU-12 is of -10 p.p.), which is not fully compensated for by higher credit market

latter we split total net saving into government and private saving. This was not done in the US studies, which makes the comparison more difficult.

${ }^{47}$ According to Asdrubali et al. (1996) results for the 1964-1990 period.

G.E.M.F. - F.E.U.C. 
smoothing, i.e. government lead smoothing ( +6 p.p.). Hence, such eventual enlargement is not likely to pose additional problems for risk sharing in the euro-zone.

With regard to the pattern of consumption smoothing over time, we started by considering two sub-periods (1971-85 and 1986-99). Over these two sub-periods, the major channels of risk sharing show great stability. However, while the aggregated contribution of saving remains roughly the same, the contribution from government and private saving differs radically between both sub-periods. Consequently, we opted for considering three sub-periods: 1971-79, 1980-89, and 1990-99. For the whole sample of 19 OECD countries, the private saving contribution in the 1970s was relatively large (42\%). In the 1980s, this positive contribution was considerably reduced $(2 \%)$, but later partially recovered its importance in the $1990 \mathrm{~s}$ (12\%). Government saving contribution to risk sharing has increased considerably and systematically over time (from $11 \%$ in the 1970 s, to $39 \%$ in the 1980 s, and finally to $45 \%$ in the 1990 s).

When considering a half-decade subdivision we concluded that the instability in the parameter estimate of factor income in the 1990s makes it almost impossible to extrapolate the evolution of this parameter into the near future. Consequently, in our view it is not possible to claim, as Kalemli-Ozcan et al. (2003) did, that the cross-ownership of productive assets is already playing a decisive role in the euro-area making it similar to the US federation. On the contrary, even for the more recent period of 1995-1999, the total amount of idiosyncratic output shocks left unsmoothed is still 5.9 times that of the US states. Moreover, it appears that the fiscal tightening in the run-up to the single currency has lead to a decrease in the amount of shocks smoothed by the government saving behaviour.

To sum up, no large differences in the pattern of risk sharing for OECD, EU-15 and euro-area legacy countries were found in our research. Nevertheless, there are considerable differences between the euro-area and the successful monetary union of the USA: the euroarea shows much lower insurance of asymmetric shocks than the US states. Until the increasing economic integration in Europe does not lead to a substantial decrease in the incidence of idiosyncratic shocks, such shocks could impose non-negligible welfare costs. Finally, due to the relatively large importance of the public sector at providing risk sharing, especially in smoothing more persistent shocks, it does not seem likely that private capital markets can easily substitute the government, in the near future, in providing a sufficient degree of risk sharing. 


\section{Appendix A- Data Sources}

The source of data used in this study was the OECD national accounts, available from the OECD Statistical Compendium 2001, edition 1, for the period 1970-1999. However, due to the unavailability of data for certain variables, particularly for certain individual countries, data from other sources was also used, and these are described below. Despite the resulting data set being the outcome of the imposition of certain hypotheses in making data from different sources compatible, it enables us to extend our sample to 19 OECD economies, including all EU15 countries (with the exception of Luxembourg). The sample comprises of the euro countries (Austria, Belgium, Finland, France, Germany, Italy, Ireland, the Netherlands, Portugal, Spain, and Greece), along with the remaining EU countries (Denmark, Sweden, and the United Kingdom), and the five non-EU countries (Australia, Canada, Norway, United States, and Japan). ${ }^{48}$

Data is expressed in real per capita terms. Net factor income (NFI), national income (NI), and disposable national income (DNI) were deflated using the deflator of GDP. Due to the existence of blank values for 1999, we extended the following series using a simple extrapolation based on the last three years: NFI, NI, and DNI for Australia and NI and DNI for Japan. $^{49}$

\section{Classification of countries}

Based on 1995 GDP and purchasing power parities (PPPs), OECD (1999: 192) has classified the members of the organization into two groups:

- seven major OECD economies: USA, Japan, Germany, France, Italy, UK and Canada

- and smaller OECD economies (all remaining countries).

\section{Fiscal data}

To break down total net saving data into government and private components we need data on at least one of those latter variables. Since, the OECD national accounts statistics are very incomplete for both subcomponents, we used data from the OECD Fiscal Positions and Business Cycles database (also available in the OECD Statistical Compendium 2001, edition 1) for government saving. The information in the boxes below recalls the definitions concerning government saving and government net lending.

\begin{tabular}{|ll|}
\hline Government Gross Saving $=$ & Total Current Receipts - Total Current disbursements \\
\hline Government Net Saving $=$ & $\begin{array}{l}\text { Government Gross Saving }- \text { Government Consumption } \\
\text { of Fixed Capital }\end{array}$ \\
\hline
\end{tabular}

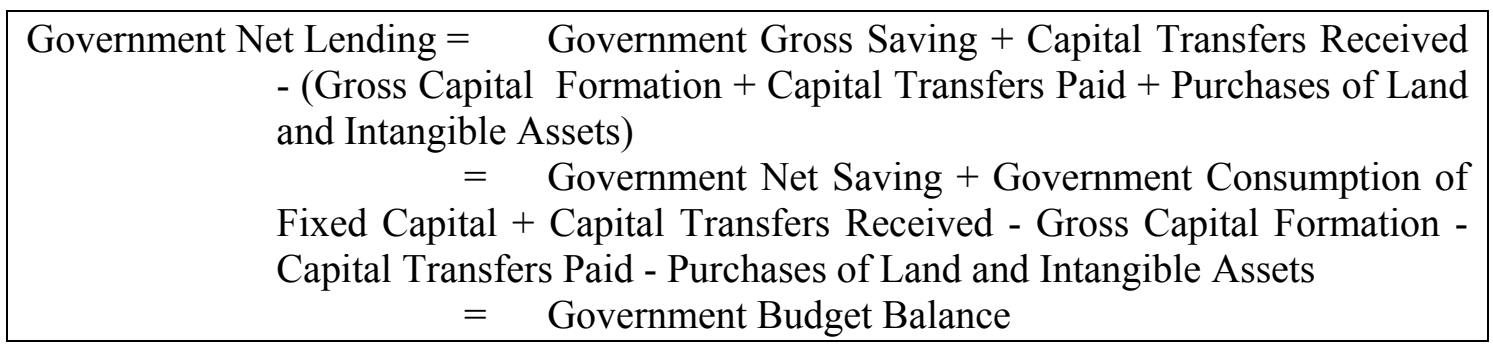

\footnotetext{
${ }^{48}$ The considered OECD countries stand for $94-95 \%$ of OECD total GDP, as reported in OECD (1999).

${ }^{49}$ For Australian NFI the extrapolation was based only on the last two years due to a change in the growth rate. 
It can be concluded from an examination of these relationships that, in order to obtain government net saving we need data on government gross saving and on government capital consumption. Government gross saving data comes from the variable "Savings, Government" of the OECD Fiscal Positions and Business Cycles (FPBC) database, complemented with data from the European Commission (2000b) for: Denmark 1970-87; UK 1970-86; and Ireland 1970-76.

The source of government net lending data (also known as the government budget balance) was again the FPBC database, complemented with data from the European Commission (2000b) on "Government budget balance" for: Denmark: 1970; UK 1970-77; Greece 1970-74; and Ireland 1970-76.

The source of data regarding government consumption of fixed capital was the "Gross saving, consumption of fixed capital government" variable of the FPBC database. Exceptions to this include data relating to: the UK, Denmark, France, Greece, and Portugal. For the UK the source of data was the variable "consumption fixed capital govt" from OECD National Accounts volume II database. Due to lack of data for Denmark, France, Greece, and Portugal in both FPBC and National accounts database, we resorted to a proxy. We assumed that the share of government capital consumption (GKC) in the total capital consumption of a nation (TKC) was directly linked to the share of public investment (GINV) in the total investment (TINV), through a moving average of two periods: ${ }^{50}$

$$
\mathrm{GKC}_{t}=\mathrm{TKC}_{t}\left(\frac{\mathrm{GINV}_{t}}{\operatorname{TINV}_{t}}+\frac{\mathrm{GINV}_{\mathrm{t}-1}}{\mathrm{TINV}_{\mathrm{t}-1}}\right)
$$

In order to make the government consumption of fixed capital compatible with the other variables (expressed in real per capita terms), we used the previous variables expressed as ratios of GDP, and resorted to the following linking method:

$$
\begin{aligned}
& \operatorname{gnsav}_{t}=\frac{\text { GovNetSaving }_{t}}{\operatorname{GDP}_{t}} \\
& \operatorname{NetSav}_{\mathrm{RPCt}}=\frac{\operatorname{gnsav}_{\mathrm{t}} * \mathrm{GDP}_{\mathrm{t}}}{\mathrm{P}_{\mathrm{t}} * \mathrm{Pop}_{\mathrm{t}}}=\operatorname{gnsav}_{\mathrm{t}} * \mathrm{GDP}_{\mathrm{RPCt}}
\end{aligned}
$$

The government net saving as a percentage of GDP was first calculated. Then, assuming, as before, the same deflator for government net saving and GDP $\left(\mathrm{P}_{\mathrm{t}}\right)$, it was only necessary to multiply government net saving expressed as a percentage of nominal GDP by real per capita GDP (GDP RPC ) to get the real per capita government net saving.

Private sector net saving was then calculated as the difference between total net saving and government net saving.

With regard to the quality of the above proxy for government consumption of fixed capital, we took the USA as benchmark, and compared the result of the proxy with actual data. The proxy only gave rise to a minor error: the average error for the period 1970-1999 being only $0.2 \%$ of GDP.

\footnotetext{
${ }^{50}$ Investment is defined as gross fixed capital formation, and its source is the OECD National Accounts volume I.
} 


\section{Appendix B- Additional Tables}

Table 10- Channels of income and consumption spending smoothing (\%): evolution over time- Further subdivision

\begin{tabular}{|c|c|c|c|c|c|c|c|c|c|c|c|c|}
\hline & \multicolumn{4}{|c|}{ All } & \multicolumn{4}{|c|}{ EU15 } & \multicolumn{4}{|c|}{ EU12 } \\
\hline & $1971-79$ & $1980-89$ & $1990-99$ & 1971-99 & 1971-79 & $1980-89$ & $1990-99$ & $1971-99$ & $1971-79$ & $1980-89$ & $1990-99$ & $1971-99$ \\
\hline \multirow[t]{2}{*}{ Factor income $\left(\beta_{\mathrm{f}}\right)$} & -2 & -2 & -1 & -2 & -1 & -4 & 0 & -1 & 0 & -1 & 2 & 0 \\
\hline & (1) & (1) & (0) & (1) & (0) & (1) & (0) & (1) & (0) & (0) & (0) & (0) \\
\hline \multirow[t]{2}{*}{ Capital Depreciation $\left(\beta_{\mathrm{d}}\right)$} & -6 & -7 & -8 & -7 & -7 & -7 & -7 & -7 & -7 & -4 & -8 & -7 \\
\hline & (4) & (3) & (4) & (7) & (4) & (3) & (3) & (6) & (3) & (1) & (3) & (6) \\
\hline \multirow[t]{2}{*}{ Internat. Transfers $\left(\beta_{t}\right)$} & -5 & 4 & 1 & -1 & -6 & 7 & 1 & -1 & -7 & 9 & 0 & -2 \\
\hline & (3) & (3) & (1) & (1) & (3) & (3) & (0) & (1) & (3) & (3) & (0) & (2) \\
\hline \multirow[t]{2}{*}{ Saving $\left(\beta_{\mathrm{s}}\right)$} & 53 & 41 & 57 & 50 & 58 & 34 & 57 & 51 & 61 & 27 & 67 & 53 \\
\hline & (8) & (7) & (9) & (15) & (7) & (4) & (7) & (12) & (7) & (3) & (7) & (11) \\
\hline \multirow[t]{2}{*}{ - Of which government } & 11 & 39 & 45 & 29 & 15 & 29 & 45 & 27 & 11 & 19 & 44 & 21 \\
\hline & (2) & (5) & (6) & (7) & (2) & (3) & (5) & (6) & (2) & (2) & (4) & (4) \\
\hline \multirow[t]{2}{*}{ - Of which private } & 42 & 2 & 12 & 21 & 42 & 4 & 12 & 24 & 50 & 8 & 22 & 32 \\
\hline & (5) & (0) & (1) & (4) & (4) & (0) & (1) & (4) & (5) & (0) & (1) & (4) \\
\hline \multirow[t]{2}{*}{ Not Smoothed $\left(\beta_{\mathrm{u}}\right)$} & 60 & 64 & 50 & 59 & 56 & 70 & 50 & 59 & 53 & 70 & 39 & 56 \\
\hline & (10) & (11) & (11) & (20) & (8) & (9) & (8) & (16) & (6) & (6) & (6) & (13) \\
\hline
\end{tabular}

Notes: see notes to Table 2 for description of the samples of countries considered. 
Table 11- Channels of income and consumption spending smoothing (\%): evolution over time- half a decade subdivision

\begin{tabular}{|c|c|c|c|c|c|c|c|c|c|c|c|c|c|c|}
\hline \multirow{4}{*}{ Factor income $\left(\beta_{\mathrm{f}}\right)$} & \multicolumn{7}{|c|}{ All } & \multicolumn{7}{|c|}{ EU12 } \\
\hline & $1971-74$ & $1975-79$ & $1980-84$ & $1985-89$ & $1990-94$ & 1995-99 & $1971-99$ & $1971-74$ & $1975-79$ & $1980-84$ & $1985-89$ & $1990-94$ & 1995-99 & $1971-99$ \\
\hline & -2 & -1 & 2 & -7 & -11 & 12 & -2 & 0 & 1 & 2 & 3 & -14 & 17 & 0 \\
\hline & (1) & (0) & (1) & (2) & (3) & (3) & (1) & (0) & (0) & (0) & (0) & (2) & (3) & (0) \\
\hline \multirow[t]{2}{*}{ Capital Depreciation $\left(\beta_{\mathrm{d}}\right)$} & -4 & -9 & -10 & -3 & -10 & -6 & -7 & -1 & -10 & -11 & 2 & -11 & -5 & -7 \\
\hline & (1) & (3) & (3) & (1) & (3) & (2) & (7) & (0) & (2) & $(2)$ & (0) & $(2)$ & (1) & (6) \\
\hline Internat. Transfers $\left(\beta_{t}\right)$ & -2 & -8 & 3 & 5 & 1 & 1 & -1 & -4 & -11 & 10 & 7 & 0 & 2 & -2 \\
\hline \multirow[t]{2}{*}{ Saving $\left(\beta_{\mathrm{s}}\right)$} & 46 & 62 & 52 & 20 & 68 & 43 & 50 & 59 & 69 & 25 & 23 & 86 & 33 & 53 \\
\hline & (4) & (7) & (6) & (3) & (7) & (5) & (15) & (2) & (5) & (2) & (2) & (5) & (2) & (11) \\
\hline \multirow[t]{2}{*}{ - Of which government } & 11 & 12 & 28 & 46 & 59 & 26 & 29 & 15 & 19 & 18 & 24 & 67 & 13 & 21 \\
\hline & (1) & (1) & (3) & (4) & (5) & (3) & (7) & (2) & (1) & (0) & (2) & (4) & (1) & (4) \\
\hline
\end{tabular}

Notes: see notes to Table 2 for description of the samples of countries considered. 


\section{References}

Arreaza, A., B. E. Sørensen and O. Yosha (1998), "Consumption Smoothing through Fiscal Policy in OECD and EU Countries", NBER Working Paper, No. W6372, [Published in: Poterba, James M., and Jurgen von Hagen (1999), eds., Fiscal Institutions and Fiscal Performance, Chicago, The University of Chicago Press, pp. 1959-1980].

ARTIS, M. and M. BUTi (2000), "Close to Balance or in Surplus: a Policy-maker's Guide to the Implementation of the Stability and Growth Pact", CEPR Discussion Paper, No. 2515, July.

Asdrubali, P., B. E. Sørensen and O. Yosha (1996), "Channels for Interstate Risk sharing: United States 1963-1990", The Quarterly Journal of Economics, CXI, 447(4), November, 1081-1110.

Baltagi, B. H. (2001), Econometric Analysis of Panel Data, $2^{\text {nd }}$ edition, Chichester: John Wiley \& Sons.

Bayoumi, T. and B. Eichengreen (1993), "Shocking Aspects of European Monetary Integration" in F. Torres and F. Giavazzi (eds.), Adjustment and Growth in the European Monetary Union, Cambridge University Press.

Buti, M. and A. SAPIR (1998), Economic Policy in EMU: a study by the European Commission Services, Oxford: Oxford University Press.

Commission of the European Communities/Eurostat, IMF, OECD, United Nations and WORLD BANK (1993), System of National Accounts 1993: United Nations publication.

Gros, D. and N. ThygeSen (1998), European Monetary Integration, Essex: Longman.

Kalemli-Ozcan, S., B. E. Sørensen and O. Yosha (2003), "Asymetric Shocks in a Monetary Union: updated evidence and policy implications for Europe", Preliminary version of the paper prepared for the European Commission, Economic and Financial Affairs, Workshop "Who will own Europe? The internationalization of asset ownership in the EU today and in the future", Brussels, February 27-28.

Krugman, P. (1993), "Lessons of Massachusetts for EMU" in F. Torres and Giavazzi (eds.), Adjustment and Growth in EMU, London: Cambridge University Press, 241-261.

MARINHeIRo, C. (2003), EMU and Fiscal Stabilisation Policy: the case of small countries, Ph.D. dissertation, Leuven: Katholieke Universiteit Leuven, forthcoming.

MÉLitz, J. and F. ZuMER (1999), "Interregional and International Risk Sharing and Lessons for EMU", Carnegie-Rochester Series on Public Policy, 51, 149-188.

OliveI, G. (2000), "Consumption Risk-Sharing Across G-7 Countries", Federal Reserve Bank of Boston, New England Economic Review, March, 3-14.

Perotti, R. (1999), "Fiscal Policy in Good Times and Bad", Quarterly Journal of Economics, November, 1399-1436.

Sørensen, B. E. and O. Yosha (1998), "International Risk Sharing and European Monetary Unification", Journal of International Economics, 45, 211-238. 


\section{Index of Tables}

TABLE 1- CHANNELS OF INCOME AND CONSUMPTION SPENDING (\%)- REPLICATION AND EXTENSION OF THE RESULTS OF ASY (1998, TABLE 3.1) ............................................ 8

TABLE 2- CHANNELS OF INCOME AND CONSUMPTION SPENDING (\%)- DIFFERENT COUNTRY SAMPLES 1971-1999

TABLE 3 - DECOMPOSITION OF SMOOTHING PROVIDED BY TOTAL NET SAVING INTO GOVERNMENT AND PRIVATE SECTORS 1971-1999

TABLE 4 - DECOMPOSITION OF SMOOTHING PROVIDED BY TOTAL NET SAVING INTO GOVERNMENT AND PRIVATE SECTORS - HIGH VS. LOW DEFICIT COUNTRIES -USING ASY DEFINITION....

TABLE 5 - DECOMPOSITION OF SMOOTHING PROVIDED BY TOTAL NET SAVING INTO GOVERNMENT AND PRIVATE SECTORS- HIGH VS. LOW DEFICIT COUNTRIES -USING DEFICIT ABOVE/BELOW AVERAGE DEFINITION

TABLE 6 - COMPARISON OF INCOME AND CONSUMPTION SMOOTHING: EU, OECD, AND US STATES - SY98 AND OUR OWN RESULTS FOR THE PERIOD 1981-1990

TABLE 7 - COMPARISON OF INCOME AND CONSUMPTION SMOOTHING: EU, OECD, AND US STATES 1970-1999

TABLE 8- CHANNELS OF INCOME AND CONSUMPTION SPENDING (\%)- 3 YEARS DIFFERENCING INTERVAL

TABLE 9- CHANNELS OF INCOME AND CONSUMPTION SPENDING (\%) -EVOLUTION OVER TIME

TABLE 10- CHANNELS OF INCOME AND CONSUMPTION SPENDING SMOOTHING (\%): EVOLUTION OVER TIME- FURTHER SUBDIVISION.

TABLE 11- CHANNELS OF INCOME AND CONSUMPTION SPENDING SMOOTHING (\%): EVOLUTION OVER TIME- HALF A DECADE SUBDIVISION 


\section{EsTUDOS DO G.E.M.F.}

(Available on-line at http://www4.fe.uc.pt/gemf)

2003

N. 2 Output Smoothing in EMU and OECD: Can We Forego Government Contribution? A risk sharing approach

- Carlos Fonseca Marinheiro

N.․ 1 Um modelo VAR para uma Avaliação Macroeconómica de Efeitos da Integração Europeia da Economia Portuguesa

- João Sousa Andrade

2002

N. 8 Discrimination des facteurs potentiels de croissance et type de convergence de l'économie portugaise dans l'UE à travers la spécification de la fonction de production macro-économique. Une étude appliquée de données de panel et de séries temporelles

- Marta Simões e Maria Adelaide Duarte

N.. 7 Privatisation in Portugal: employee owners or just happy employees?

-Luís Moura Ramos e Rita Martins

N.o 6 The Portuguese Money Market: An analysis of the daily session

- Fátima Teresa Sol Murta

N. 5 As teorias de ciclo políticos e o caso português

- Rodrigo Martins

N. 4 Fundos de acções internacionais: uma avaliação de desempenho

- Nuno M. Silva

N. 3 The consistency of optimal policy rules in stochastic rational expectations models

- David Backus and John Driffill 
N.. 2 The term structure of the spreads between Portuguese and German interest rates during stage II of EMU

- José Soares da Fonseca

N. 1 O processo desinflacionista português: análise de alguns custos e benefícios - António Portugal Duarte

N. 14 Equity prices and monetary policy: an overview with an exploratory model - Fernando Alexandre e Pedro Bação

N. 13 A convergência das taxas de juro portuguesas para os níveis europeus durante a segunda metade da década de noventa

- José Soares da Fonseca

N. 12 Le rôle de l'investissement dans l'éducation sur la croissance selon différentes spécifications du capital humain.

- Adelaide Duarte e Marta Simões

N. 11 Ricardian Equivalence: An Empirical Application to the Portuguese Economy - Carlos Fonseca Marinheiro

N.. 10 A Especificação da Função de Produção Macro-Económica em Estudos de Crescimento Económico.

- Maria Adelaide Duarte e Marta Simões

N. 9 Eficácia da Análise Técnica no Mercado Accionista Português

- Nuno Silva

N.o 8 The Risk Premiums in the Portuguese Treasury Bills Interest Rates:

Estimation by a cointegration method

- José Soares da Fonseca

N. 7 Principais factores de crescimento da economia portuguesa no espaço europeu

- Maria Adelaide Duarte e Marta Simões

N. 6 Inflation Targeting and Exchange Rate Co-ordination

- Fernando Alexandre, John Driffill e Fabio Spagnolo

N. 5 Labour Market Transition in Portugal, Spain, and Poland: A Comparative Perspective

- Paulino Teixeira

N. 4 Paridade do Poder de Compra e das Taxas de Juro: Um estudo aplicado a três países da UEM

- António Portugal Duarte 
N. 3 Technology, Employment and Wages

- John T. Addison e Paulino Teixeira

N. 2 Human capital investment through education and economic growth. A panel data analysis based on a group of Latin American countries

- Maria Adelaide Duarte e Marta Simões

N. 1 Risk Premiums in the Porutguese Treasury Bills Interest Rates from 1990 to 1998. An ARCH-M Approach

- José Soares da Fonseca

2000

N. 8 Identificação de Vectores de Cointegração: Análise de Alguns Exemplos

- Pedro Miguel Avelino Bação

N. 7 Imunização e M-quadrado: Que relação?

- Jorge Cunha

N.. 6 Eficiência Informacional nos Futuros Lisbor 3M

- Nuno M. Silva

N.o 5 Estimation of Default Probabilities Using Incomplete Contracts Data

- J. Santos Silva e J. Murteira

N. 4 Un Essaie d'Application de la Théorie Quantitative de la Monnaie à

l'économie portugaise, 1854-1998

- João Sousa Andrade

N.. 3 Le Taux de Chômage Naturel comme un Indicateur de Politique Economique? Une application à l'économie portugaise

- Adelaide Duarte e João Sousa Andrade

N.. 2 La Convergence Réelle Selon la Théorie de la Croissance: Quelles Explications pour l'Union Européenne?

- Marta Cristina Nunes Simões

N. 1 Política de Estabilização e Independência dos Bancos Centrais

- João Sousa Andrade

1999

N. 9 Nota sobre a Estimação de Vectores de Cointegração com os Programas CATS in RATS, PCFIML e EVIEWS

- Pedro Miguel Avelino Bação

N. 8 A Abertura do Mercado de Telecomunicações Celulares ao Terceiro Operador: Uma Decisão Racional?

- Carlos Carreira 
N.o 7 Is Portugal Really so Arteriosclerotic? Results from a Cross-Country Analysis of Labour Adjustment

- John T. Addison e Paulino Teixeira

N. 6 The Effect of Dismissals Protection on Employment: More on a Vexed Theme - John T. Addison, Paulino Teixeira e Jean-Luc Grosso

N. 5 A Cobertura Estática e Dinâmica através do Contrato de Futuros PSI-20. Estimação das Rácios e Eficácia Ex Post e Ex Ante

- Helder Miguel C. V. Sebastião

N. 4 Mobilização de Poupança, Financiamento e Internacionalização de Carteiras - João Sousa Andrade

N.ㄱ Natural Resources and Environment

- Adelaide Duarte

N. 2 L'Analyse Positive de la Politique Monétaire

- Chistian Aubin

N.o 1 Economias de Escala e de Gama nos Hospitais Públicos Portugueses: Uma Aplicação da Função de Custo Variável Translog

- Carlos Carreira

1998

N. 11 Equilíbrio Monetário no Longo e Curto Prazos - Uma Aplicação à Economia Portuguesa

- João Sousa Andrade

N. 10 Algumas Observações Sobre o Método da Economia - João Sousa Andrade

N.o 9 Mudança Tecnológica na Indústria Transformadora: Que Tipo de Viés Afinal?

- Paulino Teixeira

N. 8 Portfolio Insurance and Bond Management in a Vasicek's Term Structure of Interest Rates

- José Alberto Soares da Fonseca

N. 7 Financial Innovation and Money Demand in Portugal: A Preliminary Study - Pedro Miguel Avelino Bação

N.o 6 The Stability Pact and Portuguese Fiscal Policy: the Application of a VAR Model

- Carlos Fonseca Marinheiro

N.o 5 A Moeda Única e o Processo de Difusão da Base Monetária - José Alberto Soares da Fonseca 
N.o 4 La Structure par Termes et la Volatilité des Taux d'intérêt LISBOR - José Alberto Soares da Fonseca

N.. 3 Regras de Comportamento e Reformas Monetárias no Novo SMI - João Sousa Andrade

N. 2 Um Estudo da Flexibilidade dos Salários: o Caso Espanhol e Português - Adelaide Duarte e João Sousa Andrade

N.1 Moeda Única e Internacionalização: Apresentação do Tema - João Sousa Andrade

1997

N. 9 Inovação e Aplicações Financeiras em Portugal

- Pedro Miguel Avelino Bação

N. 8 Estudo do Efeito Liquidez Aplicado à Economia Portuguesa - João Sousa Andrade

N.o 7 An Introduction to Conditional Expectations and Stationarity - Rui Manuel de Almeida

N. 6 Definição de Moeda e Efeito Berlusconi - João Sousa Andrade

N. 5 A Estimação do Risco na Escolha dos Portafólios: Uma Visão Selectiva - António Alberto Ferreira dos Santos

N.o 4 A Previsão Não Paramétrica de Taxas de Rentabilidade

- Pedro Manuel Cortesão Godinho

N. 3 Propriedades Assimptóticas de Densidades

- Rui Manuel de Almeida

N. 2 Co-Integration and VAR Analysis of the Term Structure of Interest Rates: an empirical study of the Portuguese money and bond markets -João Sousa Andrade e José Soares da Fonseca

N. 1 Repartição e Capitalização. Duas Modalidades Complementares de Financiamento das Reformas

- Maria Clara Murteira

N. 8 A Crise e o Ressurgimento do Sistema Monetário Europeu - Luis Manuel de Aguiar Dias

N. 7 Housing Shortage and Housing Investment in Portugal a Preliminary View - Vítor Neves 
N. 6 Housing, Mortgage Finance and the British Economy

- Kenneth Gibb e Nile Istephan

N. 5 The Social Policy of The European Community, Reporting Information to Employees, a U.K. perspective: Historical Analysis and Prognosis

- Ken Shackleton

N. 4 O Teorema da Equivalência Ricardiana: aplicação à economia portuguesa - Carlos Fonseca Marinheiro

N. 3 O Teorema da Equivalência Ricardiana: discussão teórica - Carlos Fonseca Marinheiro

N. 2 As taxas de juro no MMI e a Restrição das Reservas Obrigatórias dos Bancos - Fátima Assunção Sol e José Alberto Soares da Fonseca

N.o 1 Uma Análise de Curto Prazo do Consumo, do Produto e dos Salários - João Sousa Andrade 